REBECCA M. BLANK

Northwestern University

DA VID CARD

Princeton University

\title{
Poverty, Income Distribution, and Growth: Are They Still Connected?
}

Macroeconomic Growth has long been viewed as one of the most effective ways to reduce poverty. Historically, the rising tide of labor market opportunities that accompanies an economic expansion has helped the poor more than the rich, leading to a narrowing of the income distribution and a fall in poverty. ${ }^{1}$ Using data from the 1950s through the 1970s, for example, Rebecca M. Blank and Alan S. Blinder estimate that a one percentage point reduction in unemployment lowers the poverty rate by one point. ${ }^{2}$ Economic growth in the 1980 s, however, seems to have had far weaker redistributive effects. ${ }^{3}$ The economic expansion from 1983 to 1989 led to a more than four percentage point decline in unemployment, but only a modest decline in aggregate poverty. Furthermore, family income inequality increased steadily throughout the decade. As shown in figure 1, the income shares of the three lowest quintiles

This research was supported by the Brookings Institution, the Industrial Relations section of Princeton University, and the National Science Foundation. We thank Gordon Dahl, Rebecca London, and Zesheng Zhang for excellent research assistance. We thank members of the Brookings Panel, and particularly our discussants, Frank Levy and James Medoff, for useful discussion comments.

1. See Blank and Blinder (1986) and Beach (1977).

2. Blank and Blinder (1986).

3. For a discussion of the changing relationship between the macroeconomy and poverty and income distribution, see Blank (1993), Cutler and Katz (1991), and Tobin (forthcoming). 
Figure 1. Quintile Shares of Total Income, 1967-91

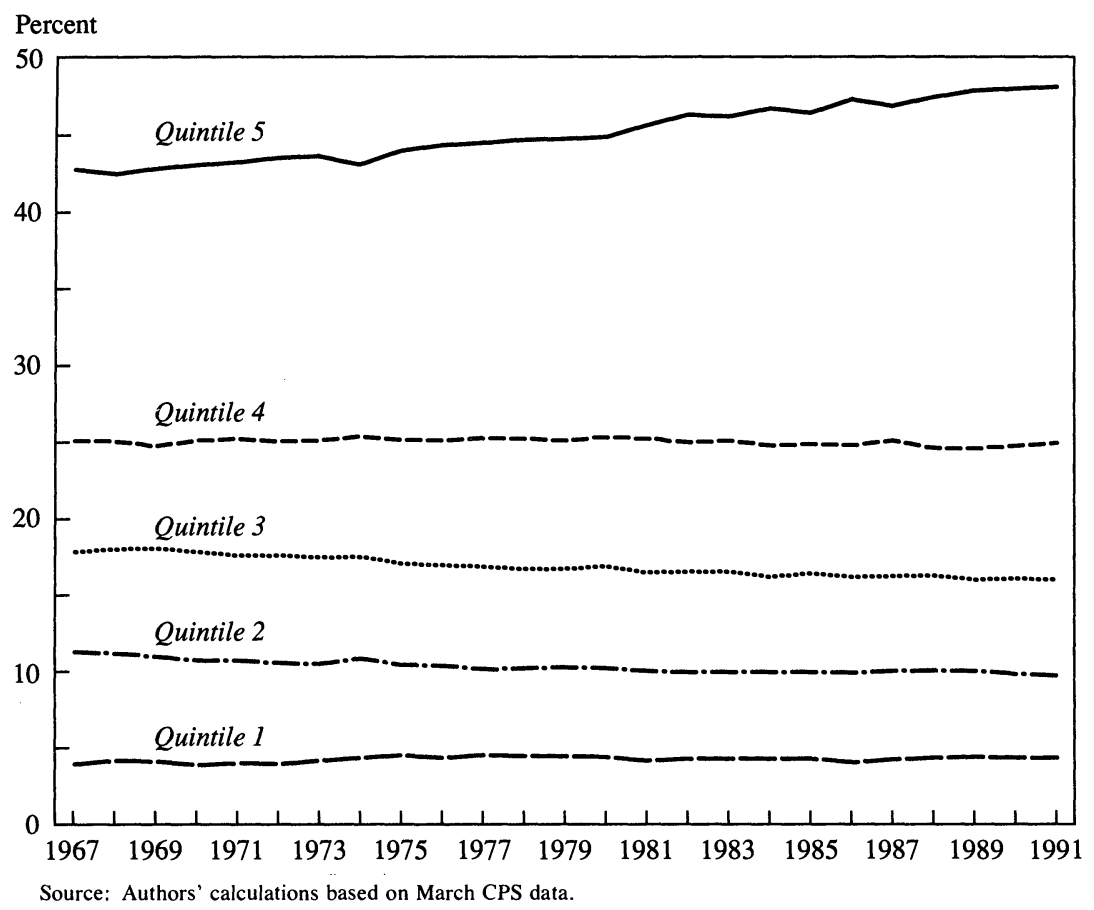

of the income distribution fell during the 1980s, while the share of the top quintile rose. ${ }^{4}$

Several explanations have been offered for the rising income inequality and stubbornly high poverty rates of the past decade. One hypothesis is that changes in household composition or shifts in the labor market attachment of low-income workers have clouded the relationship between aggregate growth, poverty, and the income distribution. While rejecting this explanation, Blank's 1993 work, as well as a 1991 study by David M. Cutler and Lawrence F. Katz, emphasizes the effect of widening wage inequality. ${ }^{5}$ For reasons that are only partially understood, the

4. Mean income in the bottom quintile fell from a high of $\$ 6,425$ (1991 dollars) in 1977 to a low of $\$ 5,940$ in 1991 . Mean income in the top quintile rose by $\$ 9,000$ during this same time period. The data underlying these calculations are described in more detail in the next section.

5. Blank (1993) and Cutler and Katz (1991) also investigate whether the actual decline in poverty over the 1980 s was understated by measurement errors in the official poverty measure. This does not appear to have happened. 
Table 1. Components of GDP Growth, 1959-89

Percent per year

\begin{tabular}{ccccccc}
\hline & & \multicolumn{2}{c}{$\begin{array}{c}\text { Decomposition } \\
\text { by employment }\end{array}$} & & \multicolumn{2}{c}{$\begin{array}{c}\text { Decomposition } \\
\text { by hours }\end{array}$} \\
\cline { 3 - 6 } \cline { 5 - 7 } Period & $\begin{array}{c}\text { Real GDP } \\
\text { per capita }\end{array}$ & $\begin{array}{c}\text { Real GDP } \\
\text { per employee }\end{array}$ & $\begin{array}{c}\text { Employment } \\
\text { per capita }\end{array}$ & & $\begin{array}{c}\text { Real GDP } \\
\text { per hour } \\
\text { of work }\end{array}$ & $\begin{array}{c}\text { Hours of } \\
\text { work per } \\
\text { capita }\end{array}$ \\
\hline $1959-69$ & 2.7 & 2.1 & 0.6 & 2.5 & 0.2 \\
$1969-79$ & 1.8 & 0.4 & 1.3 & & 1.0 & 0.8 \\
$1979-89$ & 1.5 & 0.7 & 0.8 & & 1.0 & 0.5 \\
$1983-89$ & 2.7 & 1.1 & 1.6 & & 1.2 & 1.5 \\
\hline
\end{tabular}

Source: Authors' calculations based on Economic Report of the President (1993, tables B1, B29, B31, and B42); Employment and Earnings (April 1970, table C-1, p. 89, and April 1990, table C-1, p. 113); and National Income and Product Accounts (NIPA). All monetary data are calculated in 1991 dollars.

a. Aggregate hours are calculated by multiplying the number of employees by average hours of work per week by 48 , where 48 represents the typical weeks at work per year among full-time workers.

wages of less skilled workers grew more slowly during the 1980s than average wages in the economy. ${ }^{6}$ The rise in wage dispersion has presumably contributed to the widening of the income distribution.

Other analysts have pointed to the slow rate of productivity growth during the 1980s. ${ }^{7}$ Table 1 presents some comparative data on income and productivity growth for the past three decades. Judged in terms of output growth, the economic expansion of the 1980 s was not too different from the expansion of the 1960s: real GDP per capita rose by 2.7 percent per year from 1983 to 1989 , identical to the 2.7 percent growth rate from 1959 to 1969. The primary source of GDP growth in the 1960s was growth in output per worker: productivity grew at 2.1 percent per year over the decade. In the 1980 s, by comparison, output per worker grew at a much slower pace, 1.1 percent per year. Most of the expansion in aggregate output in the 1980s was due to employment growth. As also shown in table 1, the conclusion is similar in the case of growth rates in GDP per hour, rather than per employee: productivity per worker or per hour grew slowly during the 1980s. Thus, if productivity gains are the conduit between macroeconomic growth and income distribution, it may not be too surprising that the economic expansion of the $1980 \mathrm{~s}$ failed to substantially lower poverty or narrow income inequality.

Despite the plausibility of a link between wage inequality and family income inequality, or between productivity growth and the earnings of

6. For documentation of this trend and a discussion of its underlying determinants, see Juhn, Murphy, and Pierce (1993), Karoly (1993), and Levy and Murnane (1992).

7. See Tobin (forthcoming) and Slottje (1989). 
low-wage workers, the available evidence on the determinants of the U.S. income distribution is limited. Existing studies rely on a handful of annual observations to compare the responsiveness of aggregate poverty rates or income shares to economic growth or unemployment rates over time. Because of data limitations, many of the statistical relations are imprecisely estimated, and only a few covariates can be investigated simultaneously. Few previous studies have distinguished between growth in aggregate output and growth in productivity. No study tries to directly estimate the effect of rising wage inequality on poverty rates or income shares. ${ }^{8}$

In this paper, we seek to expand the available evidence on the determinants of the income distribution and the poverty rate. We link regional information on earnings, incomes, and poverty rates for nine regions of the United States to region-specific data on regional unemployment rates, as well as the level and dispersion of hourly wages. As we shall show, striking differences in the patterns of economic growth, unemployment, and wage inequality occur across regions. These differences provide a rich proving ground for evaluating alternative hypotheses about the link between poverty, income distribution, and economic change.

The next section of this paper describes the longitudinal data set of regional income and poverty statistics that we have assembled from U.S. Bureau of the Census Current Population Survey (CPS) microdata files available as tape data sets. The third section investigates the connection between aggregate indicators of economic well-being (unemployment rates and median income growth) and the distribution of income, and analyzes the stability of this relationship over time. In the fourth section, we examine how income distribution responds to changes in the labor market, investigating the combined effects of unemployment rates, median wage rates, and the dispersion of hourly wages. The fifth section briefly describes the role of family composition in widening income inequality. The sixth section focuses explicitly on poverty rates and their relationship to economic change. In the last section, we summarize our findings and draw some conclusions.

8. Blank (1993) and Cutler and Katz (1991) treat the effect of rising wage inequality as a residual, rather than attempting to measure it directly. 


\section{Data Description}

We used information from the March Current Population Survey to construct family income statistics and poverty rates by region and by year. The March CPS collects retrospective information on weeks of employment and unemployment, total earnings, and income for the previous calendar year. Consistent surveys are available from 1968 through 1992, providing information for 1967 through 1991, a total of twenty-five years. For each year, we computed averages of labor market and income variables by region for the nine U.S. census divisions by income quintile within region, and by family type within each income quintile. This breakdown yields a total of 9,000 observations: ten regional observations (nine regions, plus the total United States) for six income categories (five income quintiles, plus the total region) and six family types (five family types, plus all families) for twenty-five years. Our data set includes employment rates for family heads and other family members, weeks of employment or unemployment, total earnings of family heads and other family members, total family income, and demographic information on the individuals within each region-quintile-family type cell. ${ }^{9}$

The micro-level household unit that forms the basis of our statistical analysis is what we will call a "family unit." Conceptually, a family unit is a set of related individuals who live in the same household. Persons who live alone or with other unrelated individuals are treated as a family unit with one family member. In contrast, the U.S. Census Bureau treats unrelated individuals (persons who live without other family members) as fundamentally different from other families and provides no data that combine both types of family units. This feature of official poverty and income distribution statistics is potentially troubling because of the rising fraction of single-person family units in the population and the implied selectivity biases that arise in analyzing either type of family unit in isolation.

9. During the 1968-92 period, the March CPS supplement was revised several times, resulting in changes in the estimated coverage of reported income in the CPS (U.S. Bureau of the Census, 1991, appendix C, and U.S. Bureau of the Census, 1992a, appendix C). In addition, nonresponse rates and imputation procedures have changed, as have top-coding limits on income components. We have not attempted to incorporate any of these changes in our data, relying instead on the use of year effects in our statistical models to capture these and other measurement-related changes. 
Within the population of family units, we distinguish five family types: families headed by an elderly person; families with children (under age 19) headed by a nonelderly single person; ${ }^{10}$ families without children headed by a nonelderly single person; ${ }^{11}$ families with children headed by a nonelderly married person; and families without children headed by a nonelderly married person.

The fractions of these different family types are illustrated in the top panel of table 2 . The fraction of family units headed by an elderly person has been relatively constant over the past twenty-five years, whereas the fraction of family units headed by single persons has grown, and the fraction headed by married persons has fallen. The rise in proportion of family units headed by single people without children is striking: by 1991, this was the largest single family type. Married couples with children, which accounted for 39.6 percent of all family units in 1967, represented less than one-quarter of family units in 1991.

We define a family unit as poor if its total family income falls below the official poverty threshold based on its size and composition. Because we are combining census family groupings and unrelated individuals, our poverty rate for family units lies between the official rate for unrelated individuals and the official rate for families. Figure 2 graphs our estimated poverty rate, labeled "all family units," against the official rates. Apart from a trend factor (which is mainly attributable to the strong downward trend in poverty rates for unrelated individuals), our composite poverty rate for family units tracks the official poverty rate for census families very well. Indeed, a regression of our poverty rate against the official family poverty rate (including an intercept and a time trend) produces a coefficient of 1.04 and an R-squared of 0.93 .

The changing family unit composition of the poor population is illustrated in the second type of family unit shown in table 2 . In 1967, 40 percent of poor family units were headed by an elderly person and 18 percent were headed by married couples with children. Twenty-five years later, the fraction of family units headed by an elderly person had fallen dramatically (driven by a large drop in the poverty rate for the elderly),

10. According to calculations using March CPS data, 85 percent of these families were headed by single females in 1991.

11. In 1991, 88 percent of these family units were composed of unrelated individuals, although unmarried but related individuals sharing the same housing unit also appear in this category. 
Table 2. Family Unit Composition of Overall Population, Poor Population, and Family Income Quintiles, 1967-91

Percent of total within subsample

\begin{tabular}{|c|c|c|c|c|c|c|}
\hline \multirow[b]{2}{*}{ Subsample } & \multirow[b]{2}{*}{ Year } & \multirow[b]{2}{*}{$\begin{array}{c}\text { Elderly } \\
\text { head }\end{array}$} & \multicolumn{2}{|c|}{ Single heads } & \multicolumn{2}{|c|}{ Married heads } \\
\hline & & & $\begin{array}{c}\text { With } \\
\text { children }\end{array}$ & $\begin{array}{l}\text { Without } \\
\text { children }\end{array}$ & $\begin{array}{c}\text { With } \\
\text { children }\end{array}$ & $\begin{array}{l}\text { Without } \\
\text { children }\end{array}$ \\
\hline \multirow{3}{*}{ All family units } & 1967 & 19.3 & 5.3 & 15.6 & 39.6 & 20.2 \\
\hline & 1979 & 19.6 & 7.9 & 24.1 & 29.4 & 19.0 \\
\hline & 1991 & 20.4 & 9.3 & 28.9 & 24.0 & 17.4 \\
\hline \multirow[t]{3}{*}{ Poor family units ${ }^{a}$} & 1967 & 40.1 & 13.4 & 23.1 & 17.5 & 5.8 \\
\hline & 1979 & 27.5 & 22.5 & 32.1 & 13.4 & 4.5 \\
\hline & 1991 & 20.8 & 26.9 & 35.2 & 13.1 & 4.1 \\
\hline \multirow{3}{*}{$\begin{array}{l}\text { First quintile } \\
\text { family units }\end{array}$} & 1967 & 49.0 & 9.0 & 27.8 & 7.0 & 7.2 \\
\hline & 1979 & 39.7 & 14.4 & 36.3 & 5.4 & 4.3 \\
\hline & 1991 & 31.1 & 19.1 & 40.7 & 5.6 & 3.4 \\
\hline \multirow{3}{*}{$\begin{array}{l}\text { Second quintile } \\
\text { family units }\end{array}$} & 1967 & 23.6 & 8.7 & 23.4 & 27.8 & 16.4 \\
\hline & 1979 & 28.6 & 11.4 & 34.6 & 15.7 & 9.7 \\
\hline & 1991 & 30.8 & 11.4 & 37.5 & 12.8 & 7.4 \\
\hline \multirow{3}{*}{$\begin{array}{l}\text { Third quintile } \\
\text { family units }\end{array}$} & 1967 & 10.1 & 4.8 & 14.1 & 50.2 & 20.9 \\
\hline & 1979 & 15.2 & 8.0 & 28.0 & 30.6 & 18.2 \\
\hline & 1991 & 20.1 & 8.4 & 34.0 & 22.7 & 14.7 \\
\hline \multirow{3}{*}{$\begin{array}{l}\text { Fourth quintile } \\
\text { family units }\end{array}$} & 1967 & 6.4 & 2.4 & 7.2 & 58.5 & 25.5 \\
\hline & 1979 & 8.3 & 4.1 & 15.1 & 45.6 & 26.9 \\
\hline & 1991 & 11.9 & 5.9 & 22.7 & 35.9 & 23.7 \\
\hline \multirow{3}{*}{$\begin{array}{l}\text { Fifth quintile } \\
\text { family units }\end{array}$} & 1967 & 6.1 & 1.4 & 4.8 & 56.2 & 31.5 \\
\hline & 1979 & 6.2 & 1.9 & 6.6 & 49.4 & 35.9 \\
\hline & 1991 & 8.7 & 1.9 & 10.2 & 42.0 & 37.1 \\
\hline
\end{tabular}

Source: Authors' calculations based on March CPS files, released by the U.S. Bureau of the Census as tape data sets. Each year's data set is a file containing household-level data for $60,000-70,000$ households and person-level data for $150,000-200,000$ adults (age 16 or older) in these households. We used the March 1968 to March 1992 data sets, which report annual data for the previous year (1967-91).

a. Poor family units are those with total income below the official poverty threshold.

while the fraction of family units headed by a single person in the poor population had risen (mainly because of increases in the overall fraction of single-headed families, rather than any relative change in poverty rates for single-headed families).

Within each region, we compute the quintiles of family income across all family units. We then assign each family unit to a quintile and compute mean income by quintile and the share of total income received by family units in each quintile. As indicated in figure 1, the resulting quintile shares show a declining fraction of total income for quintiles 1-3 over the past two decades, coupled with a rise in the share for 
Figure 2. Family and Individual Poverty Rates, 1967-91

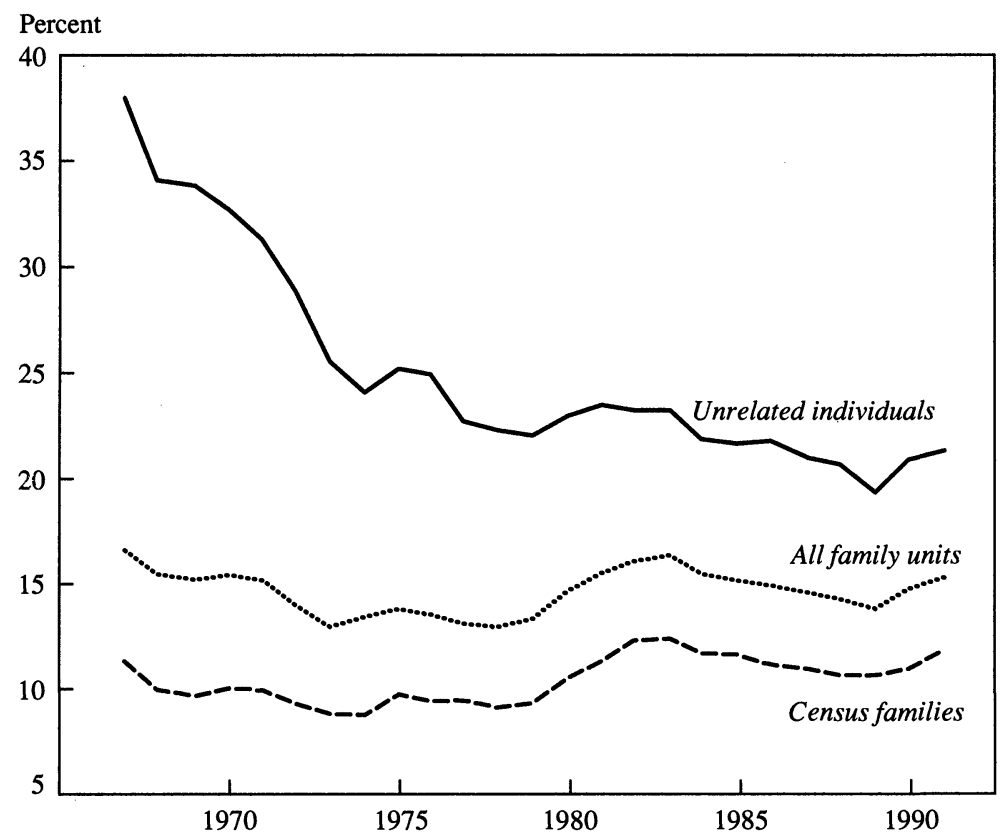

Source: Authors' calculations based on March CPS data and U.S. Bureau of the Census (1992a, table 2, p. 2, and table c, p. xiv).

quintile 5. These patterns are very similar to the trends in published data on quintile shares for census families.

The family composition of the five income quintiles is summarized in the five lower panels of table 2. Consistent with their declining share of the poor population, family units headed by elderly persons have become a smaller fraction of the first quintile, and a larger fraction of quintiles 2 and 3 . At the same time, the fraction of family units headed by a single person in quintile 1 has risen from 37 to 60 percent. Most family units in the fourth and fifth quintiles are headed by married couples.

Regional Variation in Income Growth, Poverty, and Income Distribution

A primary goal of this paper is to use differences in regional growth rates to estimate the effects of economic change on poverty and the income distribution. If regional data are to provide more information than 
Table 3. Unemployment Rates, Per Capita Income, and Median Family Income by Region, 1969-89a

\begin{tabular}{|c|c|c|c|c|c|c|c|c|c|c|c|}
\hline Measure & & $\begin{array}{l}\text { United } \\
\text { States }\end{array}$ & $\begin{array}{c}\text { New } \\
\text { England }\end{array}$ & $\begin{array}{l}\text { Mid- } \\
\text { Atlantic }\end{array}$ & $\begin{array}{c}\text { East } \\
\text { north } \\
\text { central }\end{array}$ & $\begin{array}{c}\text { West } \\
\text { north } \\
\text { central }\end{array}$ & $\begin{array}{c}\text { South } \\
\text { Atlantic }\end{array}$ & $\begin{array}{c}\text { East } \\
\text { south } \\
\text { central }\end{array}$ & $\begin{array}{c}\text { West } \\
\text { south } \\
\text { central }\end{array}$ & $\begin{array}{l}\text { Moun- } \\
\text { tain }\end{array}$ & Pacific \\
\hline \multirow{3}{*}{$\begin{array}{l}\text { Unemployment } \\
\text { rates }\end{array}$} & 1969 & 3.5 & 3.0 & 3.2 & 3.2 & 2.4 & 3.4 & 3.7 & 3.7 & 4.2 & 5.1 \\
\hline & 1979 & 5.8 & 5.4 & 7.0 & 6.1 & 4.0 & 5.5 & 6.1 & 4.7 & 5.1 & 6.4 \\
\hline & 1989 & 5.3 & 3.9 & 4.7 & 5.7 & 4.5 & 4.8 & 6.3 & 6.8 & 5.5 & 5.2 \\
\hline \multirow{3}{*}{$\begin{array}{l}\text { Average real } \\
\text { per capita } \\
\text { income }\end{array}$} & 1969 & 13,099 & 14,277 & 14,732 & 13,861 & 12,369 & 11,780 & 9,671 & 10,962 & 11,709 & 14,739 \\
\hline & 1979 & 15,551 & 16,147 & 16,345 & 16,300 & 15,519 & 14,212 & 12,285 & 14,571 & 14,658 & 17,413 \\
\hline & 1989 & 19,216 & 23,183 & 22,213 & 18,933 & 17,922 & 18,808 & 15,145 & 16,145 & 16,931 & 20,814 \\
\hline \multicolumn{12}{|l|}{ Growth rates in } \\
\hline real per & 1969-79 & 1.73 & 1.24 & 1.04 & 1.63 & 2.29 & 1.89 & 2.42 & 2.89 & 2.27 & 1.68 \\
\hline capita income & $1979-89$ & 2.14 & 3.68 & 3.12 & 1.51 & 1.45 & 2.84 & 2.11 & 1.03 & 1.45 & 1.80 \\
\hline \multirow{3}{*}{$\begin{array}{l}\text { Real median } \\
\text { family unit } \\
\text { income }\end{array}$} & 1969 & 28,216 & 31,213 & 29,979 & 31,743 & 26,099 & 25,108 & 21,162 & 23,613 & 28,209 & 30,677 \\
\hline & 1979 & 26,977 & 27,456 & 26,979 & 30,229 & 26,004 & 25,367 & 23,416 & 23,607 & 27,340 & 27,876 \\
\hline & 1989 & 27,786 & 32,398 & 30,980 & 29,314 & 25,550 & 26,600 & 21,917 & 23,551 & 26,057 & 29,875 \\
\hline \multicolumn{12}{|l|}{$\begin{array}{l}\text { Growth rates in } \\
\text { real median }\end{array}$} \\
\hline family unit & $1969-79$ & -0.45 & -1.27 & -1.05 & -0.49 & -0.04 & 0.10 & 1.02 & 0.00 & -0.31 & -0.95 \\
\hline income & $1979-89$ & 0.30 & 1.67 & 1.39 & -0.31 & -0.18 & 0.48 & -0.66 & -0.02 & -0.48 & 0.69 \\
\hline
\end{tabular}

Source: Authors' calculations based on March CPS files.

a. Incomes are in real dollars and are deflated using the GDP deflator, with $1991=100$. Unemployment rates are in percent. Average real per capita income and real median family unit income are in 1991 real dollars and are deflated using the GDP deflator. Growth rates are expressed as percent per year.

national data, there must be different patterns of unemployment and income growth across regions, as well as differences in poverty rates and distributional outcomes that reflect these differences in economic activity.

Table 3 indicates that there were significant regional differences in income growth and unemployment during our sample period. For example, unemployment rates in the middle Atlantic states rose faster than the national average between 1969 and 1979, while real per capita income and median family income grew more slowly than the national average. During the same period unemployment rates in the west south central states rose only modestly and incomes climbed in response to the rise in energy prices. Between 1979 and 1989, however, these relative patterns were reversed; unemployment fell and income grew rapidly in the middle Atlantic states, while unemployment rose and income stagnated in the west south central states.

Figure 3 plots the income shares of the first quintile in the nine regions between 1967-91. Most regions show a secular decline in the first quintile share, although the timing and magnitude of the decline varies, with the strongest trend in New England and relatively little trend in the 

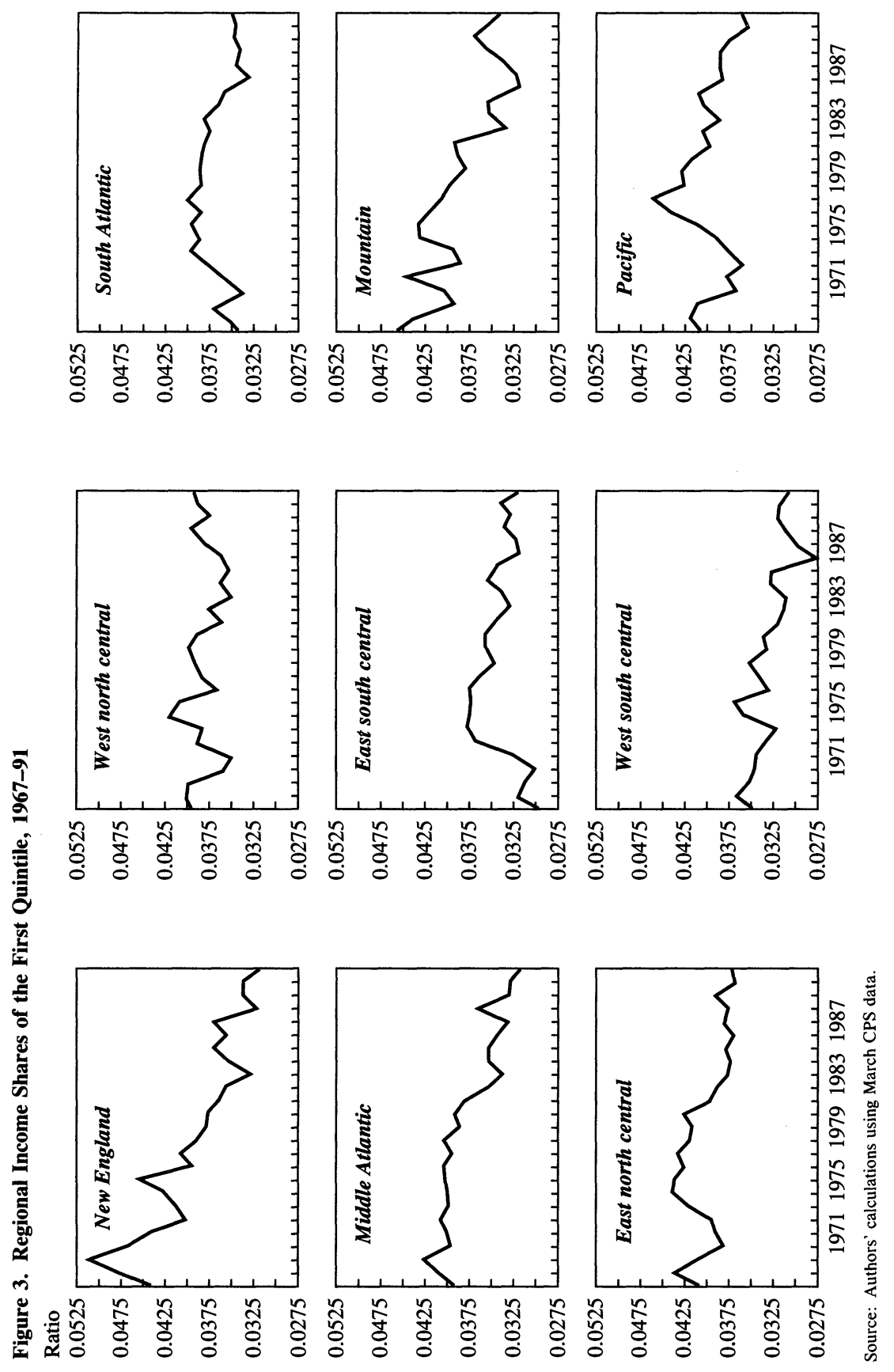
Figure 4. Poverty Rates in Selected Regions, 1967-91

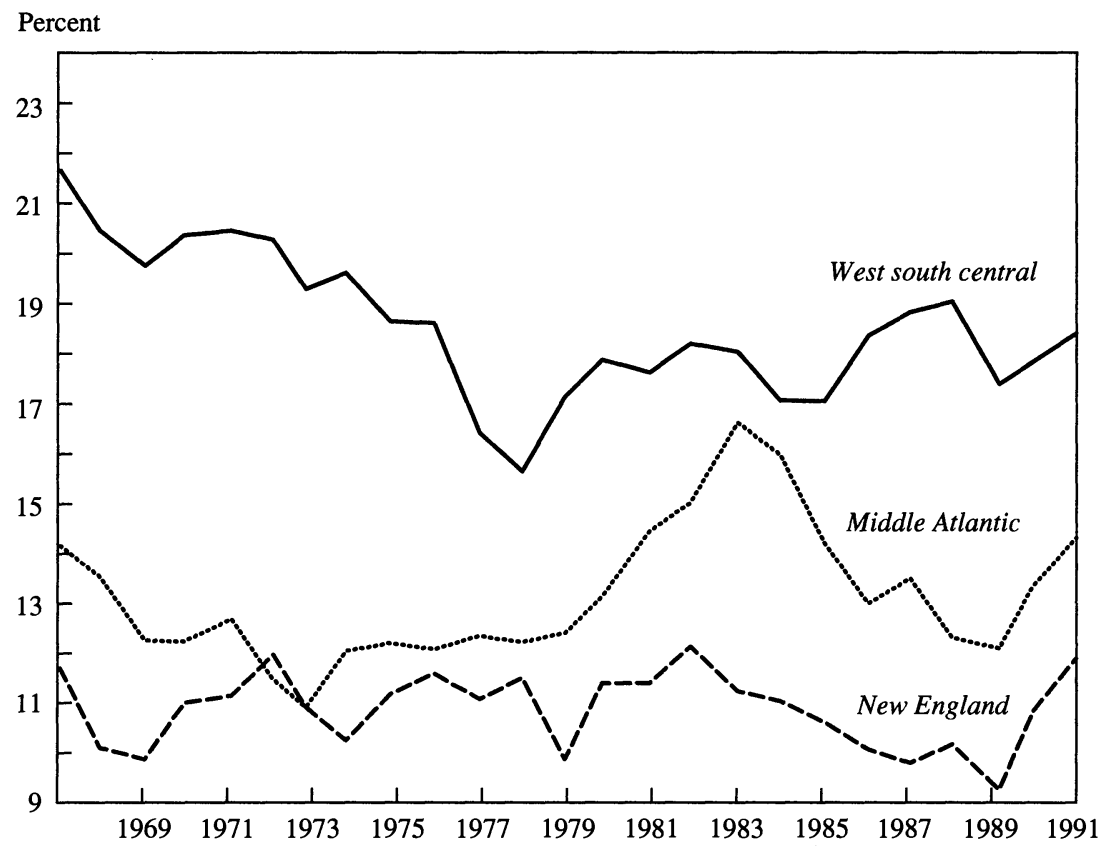

Source: Authors' calculations based on March CPS data.

west north central and south Atlantic states. Perhaps surprisingly (given the very different patterns of income growth), the middle Atlantic and west south central states show similar patterns for the first quintile share.

As shown in figure 4, poverty rates also vary in both level and trend across regions. ${ }^{12}$ The patterns in the west south central and middle Atlantic states are broadly consistent with their income trends. Relative to the middle Atlantic region, poverty rates in the west south central region declined in the 1970s and rose in the 1980s. Poverty rates in New England were relatively stable, declining modestly from 1982 to 1989 and surging rapidly upward between 1989 and $1991 .{ }^{13}$

12. For simplicity, we have only presented poverty rates in three regions.

13. At first glance, the trends in the poverty rate and the first quintile income share for New England may seem contradictory. Poverty, however, depends on the absolute level of income among the lowest-income group, rather than their relative share of income. In New England, the decline in the share of income received by the lowest quintile was offset by average income growth, leading to relative stability in the poverty rate. 
These differing regional patterns of unemployment, income growth, income distribution, and poverty allow us to study the linkages between economic growth and the well-being of low-income families with far more degrees of freedom than national-level data can provide. ${ }^{14}$ In addition, we can control for other unmeasured factors that affect outcomes in particular regions or particular years by including region and year effects in our analyses.

Specifically, we can analyze equations of the form

$$
y_{j t}=X_{j t} \beta+\alpha_{j}+\theta_{t}+u_{j t},
$$

where $y_{j t}$ represents an outcome variable such as the poverty rate for region $j(j=1,2, \ldots 9)$ and year $t\left(t=1967,1968, \ldots\right.$ 1991); $X_{j t}$ represents a set of observed control variables, such as the unemployment rate, for the region and year; $\alpha_{j}$ is a region-specific fixed effect; $\theta_{t}$ is a year-specific fixed effect; and $u_{j t}$ is a region- and year-specific error component. The region effects capture any permanent differences in the outcome variable across regions, such as differences in incomes due to regional differences in the cost of living. The year effects capture any aggregate components of the outcome variable that are common across regions in year $t$, such as differences arising from changes in the CPS questionnaire.

There are several reasons to prefer pooled time-series cross-sectional estimates-such as those estimated from equation 1-to estimates from a simple regression of the aggregate-level outcome on aggregate explanatory variables. As we just noted, the first is sample size: one cannot hope to identify the effects of more than a few explanatory variables from aggregate regressions based on twenty-five or thirty annual observations. Perhaps more importantly, the use of pooled time-series crosssectional data allows us to include unrestricted year effects. These year effects control for any unobserved aggregate-level factors, and will eliminate biases in the estimated betas arising from a correlation between the

14. There is no reason to believe that the nine U.S. census divisions are necessarily the best regional aggregation. We use them because we believe that a nine-region breakdown captures most of the geographic variation in growth patterns across the country and because there are enough observations at the regional level to produce reliable estimates of poverty and income distribution by family type using the CPS sample. In addition, the CPS samples do not separately identify all fifty states before 1976 . 
components of $X$ and unobserved factors that affect the dependent variable in all regions in a given year. For example, errors in the specification of equation 1 arising from the use of a particular price deflator will tend to affect measured real incomes or measured poverty rates in all regions of the country, and will be absorbed by the year effects.

On the minus side, it is conceivable that income and poverty in one region depend not only on aggregate conditions in that region, but on conditions in neighboring regions or throughout the rest of the country. ${ }^{15}$ In this case, the estimated coefficients from a model such as equation 1 will tend to understate the effect of aggregate demand on region-specific income or poverty outcomes. A similar problem is created by measurement error. If the region-level $X \mathrm{~s}$ are estimated with error, coefficient estimates from equation 1 may be attenuated, and some of the true explanatory power of the $X$ s will be attributed to the year effects. A third difficulty arises if some of the $X$ variables are only observed nationally. The effect of any purely aggregate variable is not identifiable in a model with unrestricted year effects.

Given a set of parameter estimates from equation 1, it is possible to investigate whether the year effects can themselves be explained by aggregate-level variables. Specifically, one can form a second stage regression

$$
\hat{\theta}_{t}=X_{t} \gamma+v_{t},
$$

where $\hat{\theta}_{t}$ represents the estimated year effect from equation $1, X_{t}$ represents the aggregate value of $X_{j t}$ (that is, the average value across all regions), and $v_{t}$ is an error term. It is important to keep in mind that the estimated coefficient vector $\gamma$ from this second-stage model is potentially biased by aggregate-level error components that happen to be correlated with $X_{t}$. Nevertheless, estimation results from the second-stage model may be informative, particularly if some components of the $X_{j t}$ vector are only available at the national level.

15. Any variation in labor market outcomes within regions can lead to an aggregation problem that manifests itself in a correlation between outcomes in one region and economic conditions in other regions. For example, poverty and family income in southern Connecticut presumably depend on labor market conditions in New York, as well as average conditions in Connecticut. This may lead to a dependence of New England's poverty rates on economic growth in the middle Atlantic region. 


\section{The Effect of Key Economic Variables on Income Distribution}

This section uses our regional panel data set to investigate the reduced-form relationship between two key economic indicators-unemployment and median income-and income distribution within regions. The unemployment rate is widely used as an indicator of the economic cycle, particularly in studies of earnings. ${ }^{16}$ Unemployment, however, summarizes only one aspect of the economic cycle. Median income can be interpreted as a broader indicator of the state of the labor market. Changes in median income reflect changes in labor force participation, changes in unemployment, and changes in real wages, all of which vary over the cycle. The relationship between a measure of the central tendency of income (such as the median) and the lower tail of the distribution is also of independent interest in light of the widespread notion that economic growth has a "trickle down" effect on lower-income families.

\section{Unemployment and the Distribution of Income}

At any point in the business cycle, unemployment is unequally distributed across the population, with higher unemployment rates among lower-wage workers. ${ }^{17}$ Likewise, cyclical increases in unemployment fall disproportionately on less skilled workers. For example, Blank and Blinder indicate that a one percentage point increase in aggregate unemployment increases unemployment among young nonwhite males by 2.5 to 3 percentage points, whereas it increases unemployment among older females (who typically work in less cyclical industries) by only about 0.8 percentage points. ${ }^{18}$

Nevertheless, cyclical changes in unemployment translate only indirectly into changes in the distribution of family income. First, many lessskilled workers live in families with other workers, spreading the burden

16. For example, Bils (1985) and Blanchflower and Oswald (forthcoming) study the effects of unemployment on real wages.

17. For example, see Card and Riddell (1993).

18. Blank and Blinder's analysis (1986, table 8.2) is based on measures of unemployment constructed from activities during the CPS survey week, whereas our analysis is based on measures of unemployment reported retrospectively. Levine (1992) compares these measures and shows that contemporaneously reported unemployment among younger workers is more cyclically sensitive than retrospective unemployment. 
of cyclical unemployment across the income distribution. Second, unemployment of one family member can potentially lead to an increase in labor supply by other family members (the "added worker" effect). Third, labor earnings contribute a smaller fraction of total family income for families at the bottom of the income distribution, implying that family income is less elastic with respect to unemployment than family earnings.

Simple tabulations suggest that although unemployment is correlated with the level of income among low-income families and thus with the poverty rate, it is less strongly related to their relative income share. The first panel of figure 5 plots the aggregate unemployment rate and our family unit poverty rate for the United States, while the second panel plots unemployment and the share of total family income received by the first two quintiles of the distribution. Movements in the poverty rate track movements in the unemployment rate rather well, especially after 1980. Movements in the income shares of quintiles 1 and 2 are less obviously correlated with unemployment.

A rise in aggregate unemployment has an unambiguously stronger impact on the weeks of unemployment reported by families at the bottom of the income distribution than at the top. The upper panel of table 4 shows the coefficient on the regional unemployment rate from regression models for total weeks of unemployment reported by family unit heads, by other adult family members, and by all adult family members. These models are estimated by quintile using regional observations for 1967-91, and include unrestricted region and year effects in addition to the regional unemployment rate as explanatory variables.

As indicated in the row for all persons, a one percentage point rise in the regional unemployment rate raises average weeks of unemployment within a family unit by twice as much in quintile 1 as in quintile $5(0.6$ weeks, compared to 0.3 weeks). ${ }^{19}$ There is a substantial difference in the distribution of cyclical unemployment among the heads of family units and other family members, however. Among heads, the rise in weeks of unemployment is heavily concentrated at the bottom of the income distribution. Among other adults, weeks of unemployment rise more in the upper quintiles than in the lower quintiles as the average unemploy-

19. For reference, the average weeks of reported unemployment by quintile are: quintile 1, 4.0 weeks; quintile 2, 3.6 weeks; quintile $3,3.3$ weeks; quintile 4, 3.0 weeks; and quintile $5,2.5$ weeks. 
Figure 5. Comparing the Unemployment Rate to the Poverty Rate and First and Second Quintiles' Share of Income, 1967-91
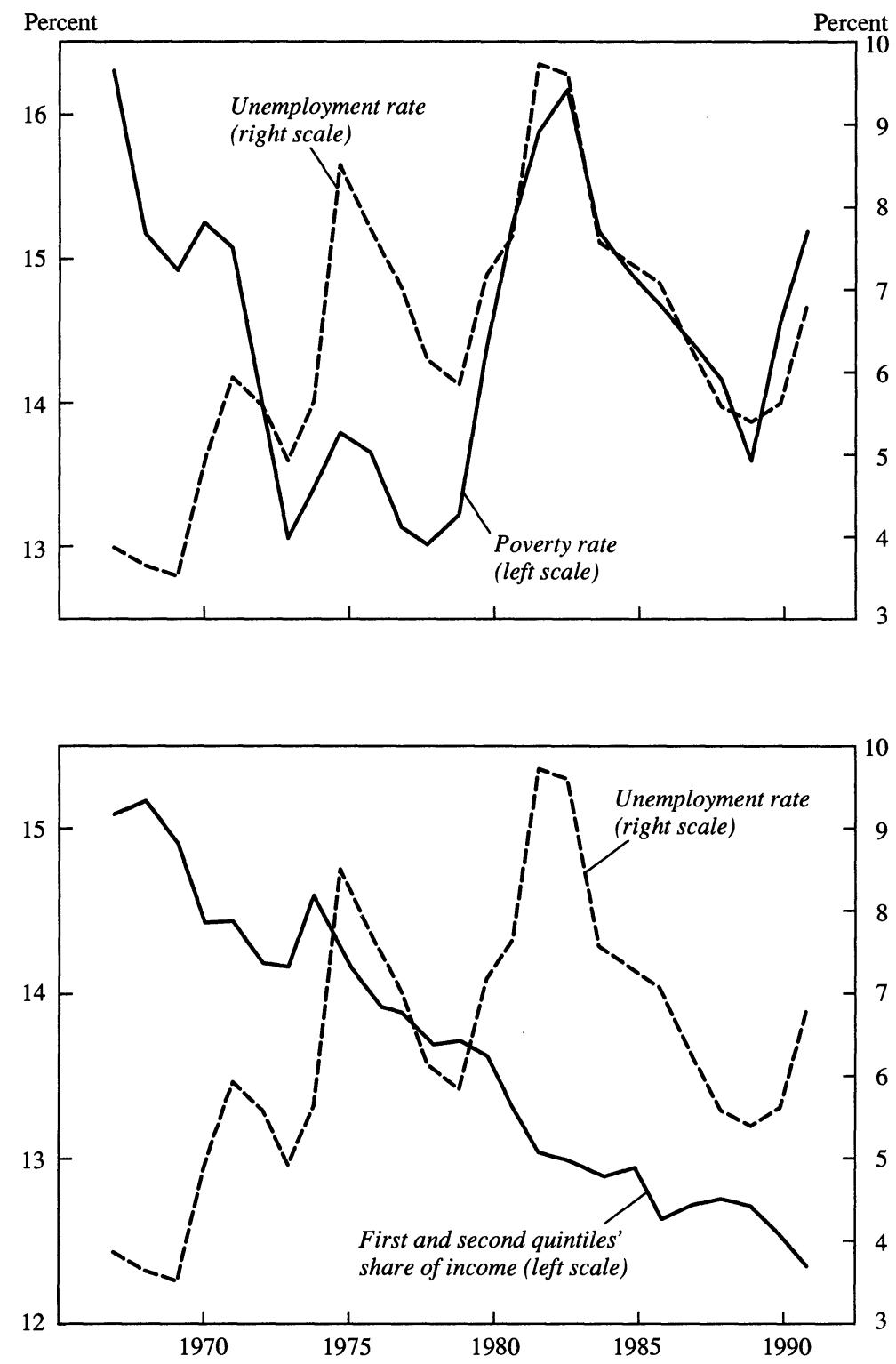

Source: Authors' calculations based on March CPS data. 
Table 4. Effect of the Unemployment Rate on Labor Market Outcomes by Quintile, 1967-91

\begin{tabular}{|c|c|c|c|c|c|c|c|}
\hline $\begin{array}{l}\text { Dependent } \\
\text { variable }\end{array}$ & $\begin{array}{l}\text { Family } \\
\text { subgroup }\end{array}$ & $A l l$ & $\underset{l}{Q u i n t i l e}$ & $\underset{2}{Q u i n t i l e}$ & $\underset{3}{Q u i n t i l e}$ & $\underbrace{Q u i n t i l e}_{4}$ & $\underset{5}{Q u i n t i l e}$ \\
\hline \multirow{3}{*}{$\begin{array}{c}\text { Total weeks } \\
\text { of unem- } \\
\text { ployment }\end{array}$} & Among heads & $\begin{array}{c}0.254 \\
(0.010)\end{array}$ & $\begin{array}{c}0.492 \\
(0.028)\end{array}$ & $\begin{array}{c}0.333 \\
(0.019)\end{array}$ & $\begin{array}{c}0.232 \\
(0.015)\end{array}$ & $\begin{array}{c}0.148 \\
(0.012)\end{array}$ & $\begin{array}{c}0.061 \\
(0.006)\end{array}$ \\
\hline & $\begin{array}{l}\text { Among other } \\
\text { adults }\end{array}$ & $\begin{array}{c}0.207 \\
(0.010)\end{array}$ & $\begin{array}{l}0.133 \\
(0.014)\end{array}$ & $\begin{array}{c}0.162 \\
(0.017)\end{array}$ & $\begin{array}{c}0.222 \\
(0.017)\end{array}$ & $\begin{array}{c}0.274 \\
(0.018)\end{array}$ & $\begin{array}{c}0.251 \\
(0.018)\end{array}$ \\
\hline & $\begin{array}{l}\text { Among all } \\
\text { persons }\end{array}$ & $\begin{array}{c}0.461 \\
(0.017)\end{array}$ & $\begin{array}{c}0.625 \\
(0.034)\end{array}$ & $\begin{array}{c}0.495 \\
(0.029)\end{array}$ & $\begin{array}{c}0.454 \\
(0.024)\end{array}$ & $\begin{array}{c}0.422 \\
(0.023)\end{array}$ & $\begin{array}{c}0.312 \\
(0.021)\end{array}$ \\
\hline \multirow{3}{*}{$\begin{array}{l}\text { Total weeks } \\
\text { of em- } \\
\text { ployment }\end{array}$} & Among heads & $\begin{array}{c}-0.374 \\
(0.043)\end{array}$ & $\begin{array}{c}-0.453 \\
(0.071)\end{array}$ & $\begin{array}{r}-0.759 \\
(0.099)\end{array}$ & $\begin{array}{c}-0.379 \\
(0.067)\end{array}$ & $\begin{array}{c}-0.194 \\
(0.039)\end{array}$ & $\begin{array}{c}-0.055 \\
(0.035)\end{array}$ \\
\hline & $\begin{array}{l}\text { Among other } \\
\text { adults }\end{array}$ & $\begin{array}{r}-0.250 \\
(0.045)\end{array}$ & $\begin{array}{c}-0.058 \\
(0.036)\end{array}$ & $\begin{array}{r}-0.128 \\
(0.065)\end{array}$ & $\begin{array}{c}-0.227 \\
(0.075)\end{array}$ & $\begin{array}{r}-0.373 \\
(0.085)\end{array}$ & $\begin{array}{r}-0.404 \\
(0.104)\end{array}$ \\
\hline & $\begin{array}{l}\text { Among all } \\
\text { persons }\end{array}$ & $\begin{array}{r}-0.624 \\
(0.063)\end{array}$ & $\begin{array}{c}-0.511 \\
(0.087)\end{array}$ & $\begin{array}{r}-0.887 \\
(0.124)\end{array}$ & $\begin{array}{c}-0.606 \\
(0.099)\end{array}$ & $\begin{array}{r}-0.567 \\
(0.094)\end{array}$ & $\begin{array}{r}-0.459 \\
(0.113)\end{array}$ \\
\hline \multirow{2}{*}{$\begin{array}{l}\text { Real average } \\
\text { weekly } \\
\text { earnings }\end{array}$} & $\begin{array}{l}\text { Among employed } \\
\text { heads }\end{array}$ & $\begin{array}{r}-2.98 \\
(1.18)\end{array}$ & $\begin{array}{c}-0.42 \\
(0.87)\end{array}$ & $\begin{array}{l}-3.17 \\
(1.14)\end{array}$ & $\begin{array}{r}-3.86 \\
(1.31)\end{array}$ & $\begin{array}{r}-3.98 \\
(1.27)\end{array}$ & $\begin{array}{l}-7.40 \\
(2.21)\end{array}$ \\
\hline & $\begin{array}{l}\text { Among other } \\
\text { employed } \\
\text { adults }\end{array}$ & $\begin{array}{r}-5.03 \\
(0.75)\end{array}$ & $\begin{array}{c}-0.75 \\
(0.92)\end{array}$ & $\begin{array}{c}-1.47 \\
(0.78)\end{array}$ & $\begin{array}{c}-2.28 \\
(0.72)\end{array}$ & $\begin{array}{r}-5.29 \\
(0.77)\end{array}$ & $\begin{array}{r}-7.56 \\
(1.26)\end{array}$ \\
\hline \multirow[t]{3}{*}{$\begin{array}{l}\text { Mean } \\
\text { earnings }\end{array}$} & Among heads & $\begin{array}{r}-288 \\
(52)\end{array}$ & $\begin{array}{l}-75 \\
(15)\end{array}$ & $\begin{array}{r}-334 \\
(56)\end{array}$ & $\begin{array}{r}-292 \\
(69)\end{array}$ & $\begin{array}{r}-278 \\
(63)\end{array}$ & $\begin{array}{l}-435 \\
(101)\end{array}$ \\
\hline & $\begin{array}{l}\text { Among other } \\
\text { adults }\end{array}$ & $\begin{array}{r}-169 \\
(20)\end{array}$ & $\begin{array}{l}-5 \\
(3)\end{array}$ & $\begin{array}{c}-29 \\
(12)\end{array}$ & $\begin{array}{c}-89 \\
(19)\end{array}$ & $\begin{array}{r}-232 \\
(32)\end{array}$ & $\begin{array}{r}-488 \\
(61)\end{array}$ \\
\hline & $\begin{array}{l}\text { Among all } \\
\text { persons }\end{array}$ & $\begin{array}{r}-457 \\
(65)\end{array}$ & $\begin{array}{c}-80 \\
(16)\end{array}$ & $\begin{array}{r}-362 \\
(63)\end{array}$ & $\begin{array}{r}-381 \\
(75)\end{array}$ & $\begin{array}{r}-511 \\
(82)\end{array}$ & $\begin{array}{r}-924 \\
(135)\end{array}$ \\
\hline
\end{tabular}

Source: Authors' regressions based on data from the March CPS files.

a. Entries are estimated regression coefficients of the regional unemployment rate for the dependent variable listed in each panel. Regressions are fit to 225 region-by-year observations based on data for the nine census regions from 1967-91. All regressions include unrestricted region and year effects. Estimated standard errors are shown in parentheses.

ment rate rises. This occurs because many workers affected by unemployment are second or third earners in higher-income households, and because higher-income households are far more likely to have multiple earners.

The second panel of table 4 shows that among all persons the decline in weeks of employment associated with a rise in aggregate unemployment is quite evenly spread across the income distribution. This relative neutrality across quintiles arises through offsetting patterns of employment losses for heads and other family members. Employment losses for 
heads occur primarily at the bottom of the income distribution, whereas employment losses of other family members occur more heavily at the top of the distribution. Interestingly, the decline in weeks of employment is consistently larger than the increase in weeks of unemployment for the top four quintiles, implying a predominant "discouraged worker" effect for these quintiles. In contrast, in the bottom quintile, the increase in weeks of unemployment is greater than the decrease in weeks of employment, implying a predominant "added worker" effect in this income range. ${ }^{20}$

Increases in unemployment are also correlated with declines in real average weekly wages among workers, as seen in the third panel of table $4 .^{21}$ The combined effect of declining hours of work and falling real wages leads to substantial declines in total earnings as the unemployment rates rises. As shown in the fourth panel of table 4, these declines occur across the income distribution, although they grow in absolute size as incomes increase. A one-point rise in the unemployment rate leads to a loss of $\$ 80$ in earnings in quintile 1 and a $\$ 924$ loss of earnings in quintile 5.

Table 5 summarizes the effects of unemployment on income and income shares by quintile. The first row reproduces the estimated earnings changes associated with a percentage point increase in unemployment among all persons, as shown in the last row of table 4 . The second row presents the mean levels of total family earnings by quintile, while the third row shows the implied percentage effect of a unit rise in unemployment on family earnings. These range from -3.7 percent for quintiles 1 and 2 to -1.4 percent for quintiles 4 and 5 .

The fourth row presents estimates of the effect of unemployment on total family income, drawing on the specification used in table 4 . Because family income equals family earnings plus nonearned income, any

20. If the effects between the pre- and post- 1980 periods are separated, virtually the entire "added worker" effect in the bottom quintile occurs after 1980. This is consistent with other evidence (Blank, 1993) indicating that an expansion in hours of work among low-income households kept family incomes higher than they would otherwise have been.

21 . The mean of average weekly wages among employed heads is $\$ 564$. Thus, the estimated coefficient in the first column for employed heads implies a -0.53 percent fall in wages for each percentage point increase in unemployment. The mean of average weekly wages among other employed family members is $\$ 291$. Thus, the estimate in the first column for other employed adults implies a -1.73 percent fall in wages for each percentage point increase in unemployment. 
Table 5. Effect of Unemployment on Mean Earnings, Mean Income, and Share of Total Family Income by Quintile, 1967-91

\begin{tabular}{|c|c|c|c|c|c|c|}
\hline Measure & All & $\begin{array}{c}\text { Quintile } \\
I\end{array}$ & $\begin{array}{c}\text { Quintile } \\
2\end{array}$ & $\underset{3}{Q u i n t i l e}$ & $\underset{4}{Q u i n t i l e}$ & $\underset{5}{\text { Quintile }}$ \\
\hline $\begin{array}{l}\text { Estimated effect of } \\
\text { unemployment on } \\
\text { mean earnings }\end{array}$ & $\begin{array}{r}-457 \\
(65)\end{array}$ & $\begin{array}{c}-80 \\
(16)\end{array}$ & $\begin{array}{r}-362 \\
(63)\end{array}$ & $\begin{array}{r}-381 \\
(75)\end{array}$ & $\begin{array}{r}-511 \\
(82)\end{array}$ & $\begin{array}{c}-924 \\
(135)\end{array}$ \\
\hline $\begin{array}{l}\text { Mean earnings }{ }^{\mathrm{b}} \\
\text { Implied percentage } \\
\text { effect }^{\mathrm{c}}\end{array}$ & $\begin{array}{r}26,794 \\
-1.71\end{array}$ & 2,137 & 9,774 & 21,043 & 35,393 & 65,109 \\
\hline $\begin{array}{l}\text { Estimated effect of } \\
\text { unemployment on } \\
\text { mean income }\end{array}$ & $\begin{array}{r}-456 \\
(68)\end{array}$ & $\begin{array}{c}-89 \\
(21)\end{array}$ & $\begin{array}{r}-274 \\
(53)\end{array}$ & $\begin{array}{r}-340 \\
(63)\end{array}$ & $\begin{array}{r}-472 \\
(80)\end{array}$ & $\begin{array}{r}-1,079 \\
(152)\end{array}$ \\
\hline $\begin{array}{l}\text { Mean income } \\
\text { Implied percentage } \\
\text { effect }^{\mathrm{c}}\end{array}$ & 33,077 & 6,180 & 15,886 & 26,907 & 40,995 & 74,848 \\
\hline $\begin{array}{l}\text { Estimated effect of } \\
\text { unemployment on } \\
\text { quintile's percentage } \\
\text { share of total income }\end{array}$ & & $\begin{array}{c}-0.00 \\
(0.01)\end{array}$ & $\begin{array}{c}-0.03 \\
(0.02)\end{array}$ & $\begin{array}{c}0.01 \\
(0.02)\end{array}$ & $\begin{array}{c}0.05 \\
(0.03)\end{array}$ & $\begin{array}{c}-0.01 \\
(0.05)\end{array}$ \\
\hline
\end{tabular}

Source: Authors' calculations and regressions based on March CPS data.

a. Estimated regression coefficients on the regional unemployment rate for mean earnings, mean income, and percentage share of total income as dependent variables, respectively. Regressions are fit to 225 region-by-year observations based on data for the nine census regions from 1967-91. All regressions include unrestricted region and year effects. Estimated standard errors are shown in parentheses.

b. The mean from 1967-91, expressed in real 1991 dollars.

c. Ratios of estimated regression coefficients of the first and fourth rows to the mean levels of earnings and income, multiplied by 100 .

discrepancy between the estimates in the first and fourth rows is attributable to cyclical patterns in nonearned income. Although one might expect changes in nonearned income to partially offset changes in earned income (reflecting unemployment insurance and other income-tested transfer payments), this is only true for quintiles $2-4$. For all five quintiles, the effect of unemployment on income is approximately equal to its effect on earnings.

The fifth row presents mean income levels by quintile and the sixth row translates the absolute effect of unemployment on income into a percentage effect. Ignoring nonlabor income, the percentage effect of unemployment on income is the percentage effect on earnings multiplied by the share of earnings in income. The higher elasticity of earnings with respect to unemployment in the lower quintiles is almost perfectly offset by the lower share of earnings in income, leading to approximately equal 
percentage changes in income for all five quintiles after a rise in unemployment. Because the effect of unemployment on a quintile's income share is (approximately) the percentage effect of unemployment on the quintile's average income minus the percentage effect on average income for all quintiles, unemployment has only a trivial effect on income shares. This conclusion is confirmed by the estimated coefficients in the last row, which are obtained by regressing the quintile income shares directly on the regional unemployment rate. None of these coefficients is large or statistically significant.

It may seem surprising that unemployment has such small effects on the income distribution. This is contrary to the conclusion reached by Blank and Blinder, ${ }^{22}$ for instance, who concluded that a rise in unemployment has a widening effect on the family income distribution from 1958-83. In part, the differences in our results stem from the inclusion of unrestricted region and year effects. Indeed, when we exclude region and year effects, we obtain coefficient estimates that indicate a more negative effect of unemployment on the shares of the lower quintiles. Inclusion of these effects-particularly the region effects-weakens the unemployment coefficient, suggesting that regions with higher average unemployment rates tend to be the regions with greater income inequality. Changes in unemployment over time, within regions, have far less effect on the income distribution.

Given the concern with changing macroeconomic effects during the 1980s, we have investigated whether the effects of unemployment on quintile income and income shares were different after 1979. As suggested in the top panel of figure 5, the effects of unemployment are, if anything, slightly stronger after 1979 than before.

Finally, it is worth emphasizing that even though unemployment has little effect on the relative distribution of income, it does affect the levels of family income. Cyclical fluctuations in unemployment are a strong predictor of family incomes throughout the income distribution. As shown in the fourth row of table 5 , each percentage point increase in unemployment is associated with a $\$ 456$ decrease in average family income, equivalent to a 1.4 percent cut in income. Again, this effect is marginally stronger in the post-1979 period, suggesting that the linkage between the unemployment rate and family income was stronger in the 1980s than in earlier decades. 
Table 6. Effect of Median Income Change on Mean Income and Share of Total Family Income by Quintile, 1967-91

\begin{tabular}{|c|c|c|c|c|c|c|}
\hline & All & $\begin{array}{c}\text { Quintile } \\
1\end{array}$ & $\begin{array}{c}\text { Quintile } \\
2 \\
\end{array}$ & $\begin{array}{c}\text { Quintile } \\
3\end{array}$ & $\begin{array}{c}\text { Quintile } \\
4\end{array}$ & $\begin{array}{c}\text { Quintile } \\
5\end{array}$ \\
\hline $\begin{array}{l}\text { Estimated effect of } \\
\text { median income on } \\
\text { mean income }\end{array}$ & $\begin{array}{c}0.982 \\
(0.037)\end{array}$ & $\begin{array}{c}0.133 \\
(0.014)\end{array}$ & $\begin{array}{c}0.664 \\
(0.037)\end{array}$ & $\begin{array}{c}1.059 \\
(0.032)\end{array}$ & $\begin{array}{c}1.283 \\
(0.049)\end{array}$ & $\begin{array}{c}1.978 \\
(0.103)\end{array}$ \\
\hline $\begin{array}{l}\text { Mean income }{ }^{\mathrm{b}} \\
\text { Implied percentage } \\
\text { effect of } \$ 1,000 \\
\text { increase in median } \\
\text { income }^{\mathrm{c}}\end{array}$ & 33,077 & 6,180 & 15,886 & 26,907 & 40,995 & 74,848 \\
\hline $\begin{array}{l}\text { Estimated effect of } \\
\text { median income on } \\
\text { quintile's percentage } \\
\text { share of total income }\end{array}$ & & $\begin{array}{c}0.013 \\
(0.010)\end{array}$ & $\begin{array}{c}0.112 \\
(0.015)\end{array}$ & $\begin{array}{c}0.099 \\
(0.017)\end{array}$ & $\begin{array}{c}0.004 \\
(0.029)\end{array}$ & $\begin{array}{r}-0.095 \\
(0.055)\end{array}$ \\
\hline
\end{tabular}

Source: Authors' calculations and regressions based on March CPS data.

a. Estimated regression coefficients of regional median income for mean income and percentage share of total income as dependent variables, respectively. Regressions are fit to 225 region-by-year observations based on data for the nine census regions from 1967-91. All regressions include unrestricted region and year effects. Estimated standard errors in parentheses.

b. The mean from 1967-91, expressed in real 1991 dollars.

c. The ratio of estimated regression coefficients in the first row to the mean levels of income in the second row, multiplied by 100 .

\section{Median Income Changes and the Income Distribution}

Although the unemployment rate appears to have few effects on the overall income distribution, this does not mean that there are no cyclical distributional changes. Over the cycle, changes in labor force participation and/or real wages may occur independently of changes in unemployment. The level of median family income is often used as a more inclusive measure of family well-being, and in this section we briefly repeat the analysis of the previous section using median income, rather than unemployment. ${ }^{23}$

Table 6 repeats the analysis in table 5, using regional changes in median income as the key independent variable. The first row shows the response of mean income in each quintile to a one dollar increase in median income. Median income growth is not spread evenly across the distribution. When the median grows by one dollar, family units in the bottom quintile experience only a $\$ 0.13$ average increase in income, while

23. We have run regressions in this section using per capita income, rather than median family income, and obtained very similar results. Either measure seems to capture the effect of aggregate income growth. 
those in the top quintile experience a $\$ 1.98$ income increase. The third row calculates the implied percentage increase in mean income in each quintile resulting from a $\$ 1,000$ rise in median family income (equivalent to a 3.7 percent increase). In aggregate, mean family incomes rise by 3 percent when median family income grows by $\$ 1,000$. The percent growth in the lowest quintile is only 2.2 percent, but the growth in quintiles 2 and 3 is larger. The net result is a redistribution away from the top and bottom quintiles and toward quintiles 2 and 3 .

This effect is illustrated by the coefficients in the fourth row of table 6 , which are obtained by regressing the quintile income shares on regional real median income. Growth in the median has no effect on income shares at the very bottom, implying that not much income trickles this far down the income distribution. Both quintiles 2 and 3, however, show significant increases in their income share with median income growth, while quintile 5 shows a significant loss of income share.

It is interesting to note that if the post-1979 effects of median income growth are allowed to differ from the earlier period, they show a weaker redistributional effect, although the coefficients are still significant and positive in quintiles 2 and 3 . Thus, there is evidence that the equalizing effect of median income growth has been weaker over the past decade than it was in earlier years, although it has not disappeared entirely.

\section{The Effects of Labor Market Changes on the Income Distribution}

The preceding section followed a "reduced form" approach to studying the connection between economic activity (summarized by the unemployment rate or real median income) and family income. In this section, we broaden the inquiry to focus on more causal models. Our approach is to take three outcomes from the labor market-the median hourly wage rate, the dispersion in hourly wages, and the unemployment rate-and treat these as determinants of the distribution of family income. We recognize that hourly wages and unemployment rates are far from being exogenous determinants of family income. Nevertheless, we believe there are important lessons to be drawn from studying the linkage between wage and unemployment outcomes and family incomes. First, the level of real wages is an observable measure of produc- 
tivity. Thus, by studying the effect of real wage growth on family incomes and poverty, we can test the extent to which productivity growth drives changes in the distribution of family incomes. ${ }^{24}$ Second, there is a large literature describing the expansion of wage inequality in the 1980 s and evaluating alternative explanations for this phenomenon. ${ }^{25}$ There is a separate literature focusing on the "productivity slowdown" and the relative stagnation of productivity and wages in the United States since the mid-1970s. ${ }^{26}$ To the extent that changes in the level and distribution of wages affect family income distribution, explanations for recent trends in the level and/or dispersion of real wages can also explain the trends in income distribution.

We emphasize that there is no mechanical connection between the level and distribution of wages, on one hand, and the level and distribution of family incomes, on the other. Intermediating between wage rates and family incomes are labor supply decisions, government transfer policies, and family formation decisions. The past decade has seen substantial shifts in all three areas. Thus, we believe it is useful to estimate the extent to which labor market forces alone (summarized by wage levels and dispersion, and unemployment) can explain changes in family income levels and distribution.

Our data on hourly earnings come from the May CPS files for 1973-78 and from the "Merged Monthly Earnings Supplements" of the 1979-91 CPS files. ${ }^{27}$ We use the median of the logarithm of hourly wages as our measure of the central tendency in wages. ${ }^{28} \mathrm{We}$ constructed several alternative measures of wage dispersion for each region and year, including the standard deviation of log wages, the gap between the ninetieth and tenth percentiles of log wages, and the gap between the seventyfifth and twenty-fifth percentiles of log wages, the interquartile range. However, problems with the presence of spikes in the wage distribution

24. One could argue that real compensation is a better measure of productivity than real wages. Our income distribution data are based on cash income, however, and are not affected by most types of nonwage compensation. During the 1980s, compensation per employee shows a similar trend to wages and salary per employee in the National Income and Product Accounts data.

25. See Levy and Murnane (1992).

26. See Baily and Gordon (1988).

27. Comparable wage data are unavailable before 1973 .

28. Hourly wages are approximately log-normally distributed. Thus, the mean and median $\log$ wage are typically within 1 or 2 percent of each other. 
Figure 6. Wage Dispersion in Selected Regions, 1973-91

Standard deviation of log wages

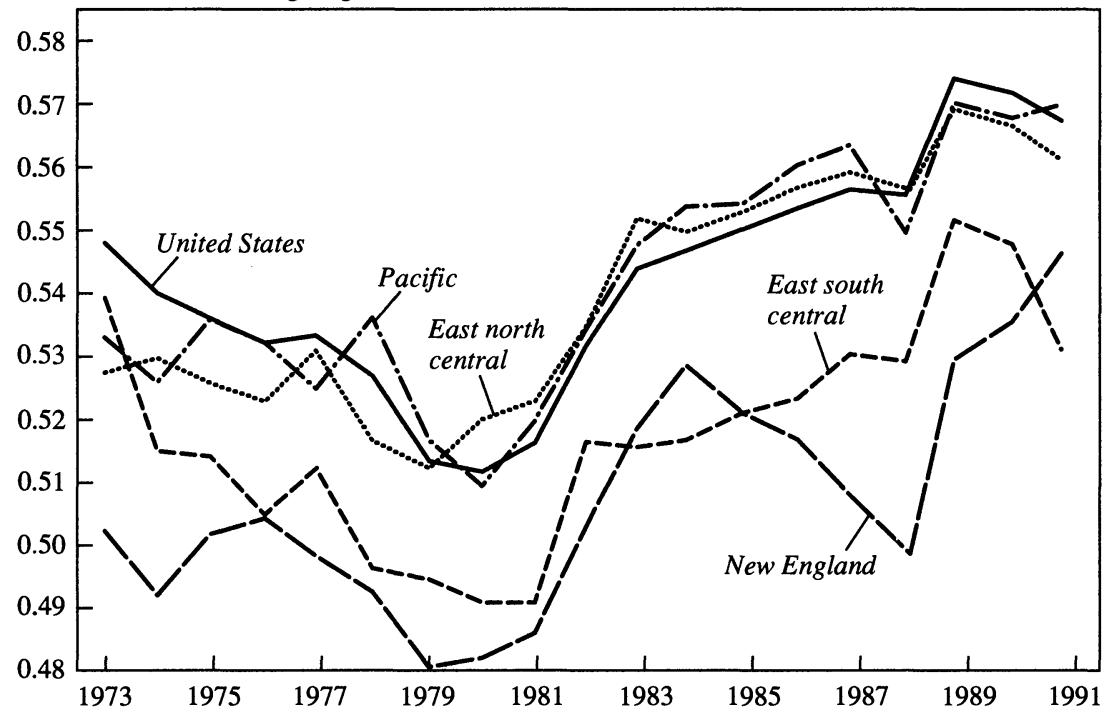

Source: Authors' calculations based on data from May CPS files for 1973-78 and the "Merged Monthly Earnings Supplements" CPS files for 1979-91.

and with the effect of the minimum wage on the lower percentiles of wages in some regions ${ }^{29}$ led us to use the standard deviation of log wages as a measure of wage dispersion.

Figure 6 plots our estimates of wage dispersion for the United States as a whole and for four selected regions. For most regions, the general pattern of wage dispersion is similar, with a decline from 1973 to 1979 or 1980, followed by a rapid rise between 1980 and $1983 .{ }^{30}$ Nevertheless, there are region-specific components of dispersion. While wage dispersion in the Pacific and east north central regions tracks aggregate U.S. wage dispersion closely, the level and the trends in wage dispersion are different in New England and the east south central states.

29. See DiNardo and Lemieux (1993).

30. Our wage dispersion measures are not strictly comparable to others in the literature for at least three reasons. First, our measures are based on reported hourly or weekly earnings for an individual's main job, rather than on total earnings and weeks of employment in the previous year. Second, we compute the dispersion of wages over all workers, not just full-time, full-year males. Third, we do not attempt to separate the "explained" and "unexplained" components of wage variance. 
Table 7. Effects of Median Wages, Wage Dispersion, and Unemployment on Mean Earnings, Mean Income, and Income Shares by Quintile, 1973-91 ${ }^{\text {a }}$

\begin{tabular}{|c|c|c|c|c|c|c|c|}
\hline $\begin{array}{l}\text { Dependent } \\
\text { variable }\end{array}$ & $\begin{array}{c}\text { Independent } \\
\text { variable }\end{array}$ & All & $\underset{l}{Q u i n t i l e}$ & $\underset{2}{Q u i n t i l e}$ & $\underset{3}{Q u i n t i l e}$ & ${\underset{4}{4}}^{\text {Quintile }}$ & $\underset{5}{\text { Quintile }}$ \\
\hline \multirow[t]{3}{*}{$\begin{array}{l}\text { Mean } \\
\text { earnings }\end{array}$} & Median log wage & $\begin{array}{l}16,603 \\
(1,445)\end{array}$ & $\begin{array}{c}1,745 \\
(406)\end{array}$ & $\begin{array}{c}7,452 \\
(1,030)\end{array}$ & $\begin{array}{l}15,546 \\
(1,414)\end{array}$ & $\begin{array}{l}22,681 \\
(2,139)\end{array}$ & $\begin{array}{l}37,242 \\
(4,172)\end{array}$ \\
\hline & Wage dispersion ${ }^{b}$ & $\begin{array}{r}-1,319 \\
(5,249)\end{array}$ & $\begin{array}{r}-1,584 \\
(1,670)\end{array}$ & $\begin{array}{r}-7,897 \\
(4,209)\end{array}$ & $\begin{array}{r}-5,943 \\
(4,561)\end{array}$ & $\begin{array}{c}6,202 \\
(8,388)\end{array}$ & $\begin{array}{r}33,632 \\
(16,791)\end{array}$ \\
\hline & $\begin{array}{l}\text { Unemployment } \\
\text { rate }\end{array}$ & $\begin{array}{r}-387 \\
(43)\end{array}$ & $\begin{array}{c}-51 \\
(15)\end{array}$ & $\begin{array}{r}-270 \\
(30)\end{array}$ & $\begin{array}{r}-240 \\
(39)\end{array}$ & $\begin{array}{r}-438 \\
(59)\end{array}$ & $\begin{array}{r}-872 \\
(127)\end{array}$ \\
\hline \multirow[t]{3}{*}{ Mean income } & Median log wage & $\begin{array}{l}18,279 \\
(1,556)\end{array}$ & $\begin{array}{c}3,165 \\
(547)\end{array}$ & $\begin{array}{r}9,343 \\
(992)\end{array}$ & $\begin{array}{l}16,174 \\
(1,356)\end{array}$ & $\begin{array}{l}23,921 \\
(2,204)\end{array}$ & $\begin{array}{l}42,511 \\
(5,078)\end{array}$ \\
\hline & Wage dispersion $^{\mathrm{b}}$ & $\begin{array}{c}1,197 \\
(5,651)\end{array}$ & $\begin{array}{r}-3,106 \\
(2,251)\end{array}$ & $\begin{array}{r}-7,750 \\
(4,054)\end{array}$ & $\begin{array}{c}3,808 \\
(5,237)\end{array}$ & $\begin{array}{l}13,028 \\
(8,540)\end{array}$ & $\begin{array}{c}32,646 \\
(20,436)\end{array}$ \\
\hline & $\begin{array}{l}\text { Unemployment } \\
\text { rate }\end{array}$ & $\begin{array}{r}-379 \\
(46)\end{array}$ & $\begin{array}{c}-26 \\
(20)\end{array}$ & $\begin{array}{r}-218 \\
(29)\end{array}$ & $\begin{array}{r}-275 \\
(37)\end{array}$ & $\begin{array}{r}-428 \\
(60)\end{array}$ & $\begin{array}{r}-970 \\
(155)\end{array}$ \\
\hline \multirow[t]{3}{*}{$\begin{array}{l}\text { Income } \\
\text { shares }\end{array}$} & Median log wage & $\ldots$ & $\begin{array}{c}-0.411 \\
(0.301)\end{array}$ & $\begin{array}{c}0.171 \\
(0.468)\end{array}$ & $\begin{array}{c}0.440 \\
(0.598)\end{array}$ & $\begin{array}{c}-1.152 \\
(0.804)\end{array}$ & $\begin{array}{r}-5.672 \\
(1.536)\end{array}$ \\
\hline & Wage dispersion ${ }^{b}$ & $\ldots$ & $\begin{array}{c}-1.885 \\
(1.237)\end{array}$ & $\begin{array}{r}-2.716 \\
(1.911)\end{array}$ & $\begin{array}{c}3.017 \\
(2.308)\end{array}$ & $\begin{array}{l}10.650 \\
(3.114)\end{array}$ & $\begin{array}{l}15.381 \\
(6.183)\end{array}$ \\
\hline & $\begin{array}{l}\text { Unemployment } \\
\text { rate }\end{array}$ & . & $\begin{array}{c}0.009 \\
(0.011)\end{array}$ & $\begin{array}{c}-0.027 \\
(0.013)\end{array}$ & $\begin{array}{c}0.002 \\
(0.016)\end{array}$ & $\begin{array}{c}0.004 \\
(0.022)\end{array}$ & $\begin{array}{r}-0.115 \\
(0.047)\end{array}$ \\
\hline
\end{tabular}

Source: Authors' regressions based on March CPS data.

a. Entries are estimated regression coefficients for the given independent variable listed to its left and based on the dependent variable shown in the first column. Regressions are fit to 171 region-by-year observations, based on data for the nine census regions from 1973-91. All regressions include unrestricted region and year effects, as well as controls for the percent of family units in central city and rural areas; the percent of family units headed by single females and elderly individuals; and the average education, percent married, and percent black among family unit heads. Estimated standard errors are shown in parentheses.

b. Wage dispersion is defined as the standard deviation of log wages.

Table 7 presents estimated regression coefficients from models that relate mean family earnings, mean family income, and family income shares by quintile within each region to regional wage levels, regional wage dispersion, and regional unemployment rates. These regressions thus control for the level and distribution of productivity, as well as the availability of job opportunities in the regional labor market. Not reported in table 7, but also included in the regression models, are unrestricted region and year effects, as well as a set of seven demographic control variables based on the average characteristics of families or family heads in each region-quintile-family type cell. ${ }^{31} \mathrm{We}$ defer a discussion of the demographic control variables to the next section.

31. These controls are the percent of family heads that are black; the percent of family units in a central city; the percent of family units outside a metropolitan area; the percent of family units headed by a single female; the percent of family units headed by an elderly person; the percent of family heads that are married; and the average education level of the family head. 
The upper panel of table 7 shows the effects of median wages, wage dispersion, and unemployment on mean earnings within each quintile. The estimated median wage coefficients confirm that higher real wages lead to higher earnings across the income distribution. To interpret the coefficients, consider the effect of a 0.05 increase in median log wages, which is about the range of variation in aggregate real wages over our sample period. A 5 percent increase in median wages increases mean earnings by about $\$ 87$ (4.1 percent) in the bottom quintile of the income distribution, and by about $\$ 1,862$ (2.9 percent) in the top quintile.

The coefficients of the wage dispersion measure show that higher wage dispersion has a negative effect on the earnings of low-income families and a positive effect on the earnings of higher-income families. During the 1980s, the standard deviation of $\log$ wages rose by about 0.05 . The estimated coefficients suggest that this change lowered the annual earnings of quintile 1 by $\$ 79$ (3.7 percent), lowered the earnings of quintile 2 by $\$ 395$ ( 4.0 percent), and raised the earnings of quintile 5 by about $\$ 1,682$ (2.6 percent).

Finally, as suggested by the regressions in table 5, the unemployment coefficients in the upper panel of table 7 show that higher unemployment reduces average family earnings across the income distribution, with larger percentage effects for the two lower quintiles. A one percentage point rise in unemployment lowers family earnings by 2.4 percent in quintile $1,2.8$ percent in quintile 2 , and by 1.1 to 1.3 percent in quintiles 3,4 , and 5 .

The effects of these labor market changes on mean incomes within each quintile are shown in the second panel of table 7. Median wage growth leads to somewhat larger percentage increases in earnings than income for all quintiles, although the coefficient estimates are relatively imprecise. Similarly, a rise in unemployment has a smaller percentage effect on income than on earnings-much smaller in quintile 1-reflecting the fact that some lost earnings are replaced through unemployment insurance and other public transfers. The sign of the effect of wage dispersion on income is the same as on earnings except for quintile 3.

The third panel of table 7 shows how these labor market changes translate into changes in income shares across the quintiles. The growth in earnings and income that occurs with a rise in median wages leads to some equalization, with a redistribution of income away from the top quintile and toward the second and third quintiles. The effect of wage 
dispersion is more clearly redistributive and is disequalizing. A rise in wage dispersion decreases the income shares of the bottom two quintiles and increases the income shares of the top three quintiles. As in table 5, changes in unemployment have little effect on the overall income distribution.

Our empirical analysis thus confirms that the level and distribution of family earnings are directly affected by the level and distribution of real wages. Real wage growth has a modest equalizing effect on family incomes, whereas increases in wage dispersion have a significant widening effect on the distribution of family incomes. Between 1979 and 1989, median wages grew slightly, unemployment fell slightly, and the standard deviation of log wages rose substantially. According to our estimates, the net effect of these labor market changes was to widen the family income distribution.

One way to see how far these labor market changes can go toward explaining the observed changes in the distribution of family incomes during the past two decades is to compare the actual changes in the aggregate income shares of the five quintiles to the "unexplained" year effects that remain when we have controlled for observed changes in median wages, the dispersion of wages, and unemployment. Figure 7 graphs the actual changes in income shares for each quintile (solid line), and the "unexplained" portion of these changes that remain in our regressions once we have controlled for the variables in our equation (dotted line)..$^{32}$ As the figure indicates, the inclusion of the control variables explains a significant fraction of the downward trend in income shares in quintiles 1-3 and virtually the entire increase in the income share of quintile 5 . However, changes in the labor market actually predict a rise in the income share of quintile 4 , whereas the fourth quintile's share fell. Thus, the unexplained downward trend in quintile 4 is larger than the actual downward trend.

To summarize, labor market developments can explain some, but not all, of the changes in the family income distribution between 1973 and 1991. There is little evidence that the income distribution has become less responsive to changes in the labor market. The dominant trend in the labor market during the past decade has been rising wage dispersion, and this has had a profound effect on the aggregate distribution of income.

32. The income share changes and unexplained components are relative to 1973. 
Figure 7. Changes in Quintile Shares, Actual and Unexplained ${ }^{\text {a }}$

Percentage change from 1973
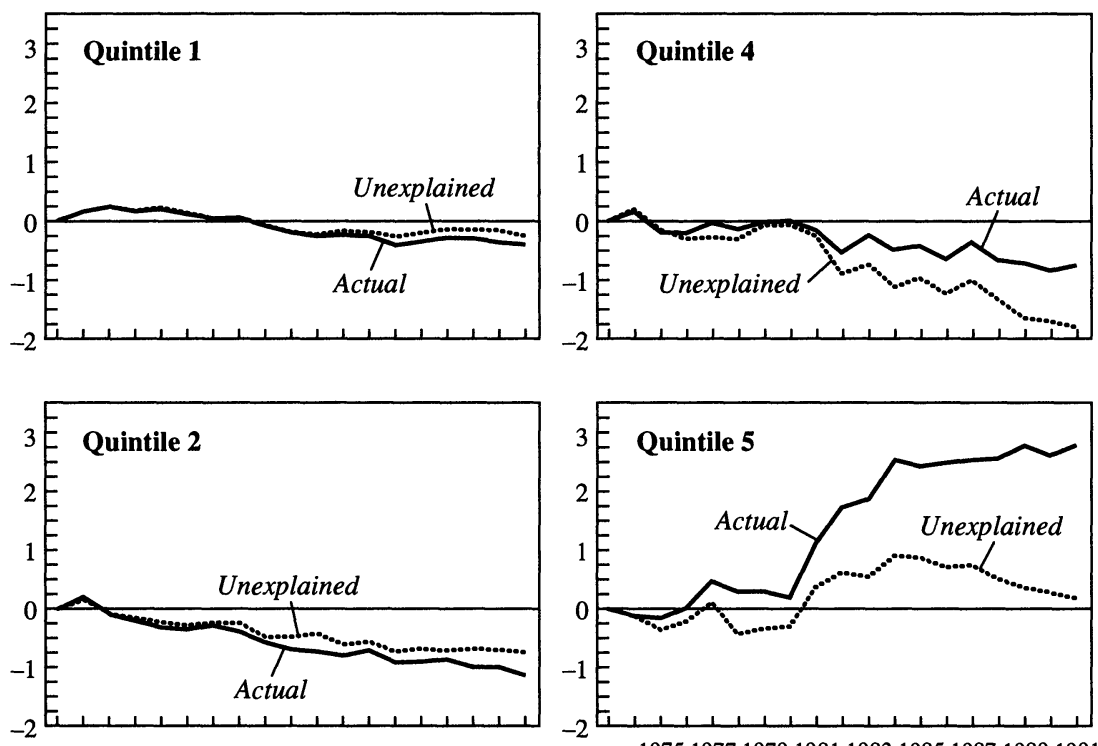

197519771979198119831985198719891991

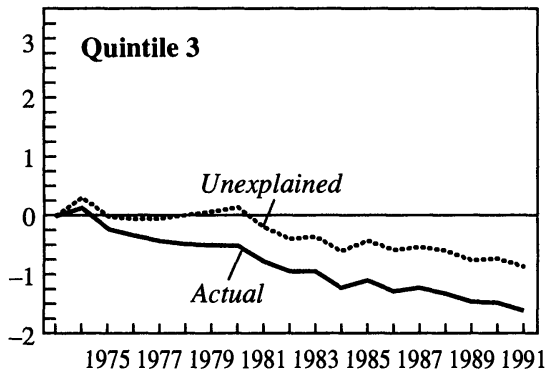

Source: Authors' calculations based on March CPS data.

a. Each panel plots the actual changes in income shares for each quintile and the unexplained portion of those changes that remain in the regressions once the authors have controlled for labor market changes.

\section{The Effect of Changing Family Composition}

Family composition has changed substantially over the past twentyfive years. More individuals live outside of nuclear families, and more families have a single person as their head. It is often suggested that the splintering of American families has contributed to the rise in family income inequality. Indeed, even if the distribution of incomes across indi- 
viduals were fixed, a rise in the fraction of smaller, poorer families (composed of families headed by females or single individuals living on their own) would increase family income inequality by widening the gap between the incomes of smaller and larger families.

To investigate the effect of changes in family composition, we calculated a family-composition constant mean income series for all families and for families in each income quintile. We calculated this series by taking the 1967 population share of each family type in each quintile and assuming that these population shares remained constant for the next twenty-five years. Thus, our family-composition constant income series allows the level of income within each family type and quintile to vary over time, but assumes that the relative shares of the family types in each quintile are fixed.

It should be noted that this income series provides only a partial measure of mean income for a particular quintile in the absence of family composition changes. We are unable to account for the effect of changing family composition on the quintile breakpoints in the income distribution. A rise in the relative number of single-headed families would be expected to lower the entire distribution of family incomes, leading to a change in the quintile breakpoints. Our family-composition constant index can only account for the differences in mean incomes across different family types in the same (fixed) income intervals. However, this problem does not affect the family-composition constant mean income calculation for all quintiles.

Table 8 shows how quintile-specific mean incomes and income shares would have changed from 1967-91 if family composition were held constant and compares these changes to the actual changes over the period. Between 1967 and 1991, average family unit income rose by $\$ 4,505$. We estimate that the growth would have been $\$ 9,293$ if family composition had held constant. Thus changing family composition has led to a $\$ 4,788$ (or 14 percent) decline in mean family income during the past two decades.

The calculations by quintile suggest that income in the bottom four quintiles would have been higher and income in the top quintile would have been lower if family composition were constant. Thus, changes in family composition have had the effect of increasing inequality in the income distribution. Nevertheless, because we are unable to account for the effects of changing family composition on the quintile breakpoints, 
Table 8. Changes in Mean Income and Income Shares by Quintile, 1967-91 ${ }^{\text {a }}$

\begin{tabular}{lcccccc}
\hline Measure and units & All & $\begin{array}{c}\text { Quintile } \\
1\end{array}$ & $\begin{array}{c}\text { Quintile } \\
2\end{array}$ & $\begin{array}{c}\text { Quintile } \\
3\end{array}$ & $\begin{array}{c}\text { Quintile } \\
4\end{array}$ & $\begin{array}{c}\text { Quintile } \\
5\end{array}$ \\
\hline $\begin{array}{c}\text { Change in 1991 dollars } \\
\text { Actual mean income }\end{array}$ & 4,505 & 267 & -904 & 124 & 4,486 & 15,437 \\
$\begin{array}{c}\text { Family-composition } \\
\text { constant mean } \\
\text { income }\end{array}$ & 9,293 & 537 & -796 & 398 & 4,851 & 15,123 \\
$\begin{array}{c}\text { Percentage change } \\
\text { Actual income share } \\
\text { Family-composition } \\
\text { constant income } \\
\text { share }\end{array}$ & $\ldots$ & -0.34 & -1.98 & -2.27 & -0.68 & 3.33 \\
\hline
\end{tabular}

Source: Authors' calculations based on March CPS data.

a. Entries represent dollar changes (measured in 1991 dollars) in mean income or percentage changes in income shares from 1967 to 1991.

b. Family-composition constant income represents a fixed-weight average of incomes by family unit type, where the weights are the shares of the family unit type in the quintile in 1967.

the estimated impact of reweighting mean incomes by family type within fixed income ranges is quite small. ${ }^{33}$

We have also estimated the responses of family-composition constant incomes by quintile to changes in unemployment rates, real wages, and wage dispersion. In general, the family-composition constant income series show the same responses as the unadjusted income series. There is no indication that changing family composition has dampened the responsiveness of family incomes to labor market changes.

Our conclusion is that family-composition changes have had a substantial effect on the level of average family income, and some widening effect on the income distribution. We are unable to give a precise estimate of the effect of changing family composition on the income shares of different quintiles. However, changes in family composition do not seem to have contributed to any weakening of the relation between labor market conditions and family income.

\section{What Affects the Poveriy Rate?}

So far, we have concentrated our analysis on the level and distribution of family income. In the remainder of the paper, we shift our focus

33. Note that the weighted average of differences within quintiles between actual income growth and family-composition constant income growth is much smaller than the average difference for all quintiles. This reflects the limitation of our family-composition constant quintile income series, which do not account for changes in quintile breakpoints in the income distribution. 
Figure 8. Poverty Rate and Real Income Deviation in the First Quintile, 1967-91

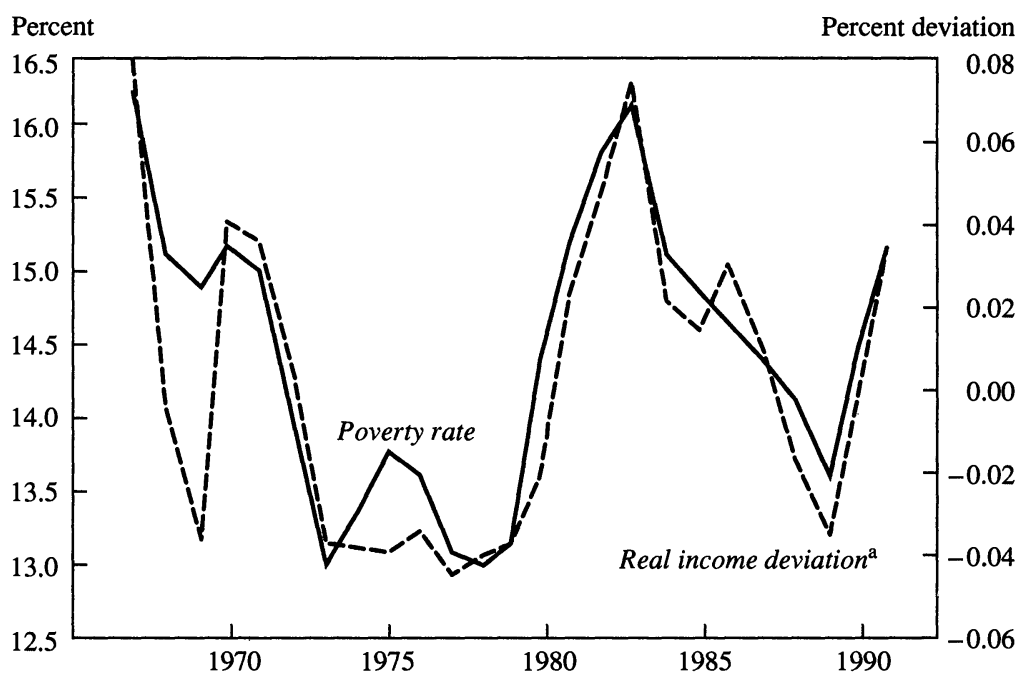

Source: Authors' calculations based on March CPS data.

a. Real income deviation equals the negative deviation from the average of log real income for the first quintile.

to the poverty rate. The poverty rate is simply the fraction of family units with real incomes below a fixed income threshold based on family size and composition. ${ }^{34}$ Consequently, movements in the poverty rate reflect both changes in the mean or median of family incomes and relative changes in the lower tail of the income distribution. ${ }^{35}$ As a practical matter, changes in the poverty rate reflect changes in the mean level of real income for the first quintile of family incomes. This is illustrated in figure 8 , where we have plotted the poverty rate for 1967-91 for all family units, along with the negative percentage deviation of real income for quintile 1 from its average value over the time period. (We use the negative deviation because poverty rises when incomes fall.) The correspondence between the two series is quite remarkable. In our panel of 225 region and

34. For a fuller discussion of issues involved in the definition of poverty, see Ruggles (1990).

35. If family income adjusted for family size, $y$, is distributed with distribution function $\mathrm{F}(y-m) / s)$, where $m$ is the mean of income and $s$ is the standard deviation, then the poverty rate is $\mathrm{F}((P-m) / s)$, where $P$ is the poverty line. Note that the derivative of the poverty rate with respect to a determinant of $m$ or $s$ will vary, depending on the density of families near the poverty rate. During the past two decades, the poverty rate has fluctuated in a relatively narrow range (13-17 percent), so it is not unreasonable to assume that the poverty rate had a fixed relationship with the determinants of the mean and dispersion of family income. 


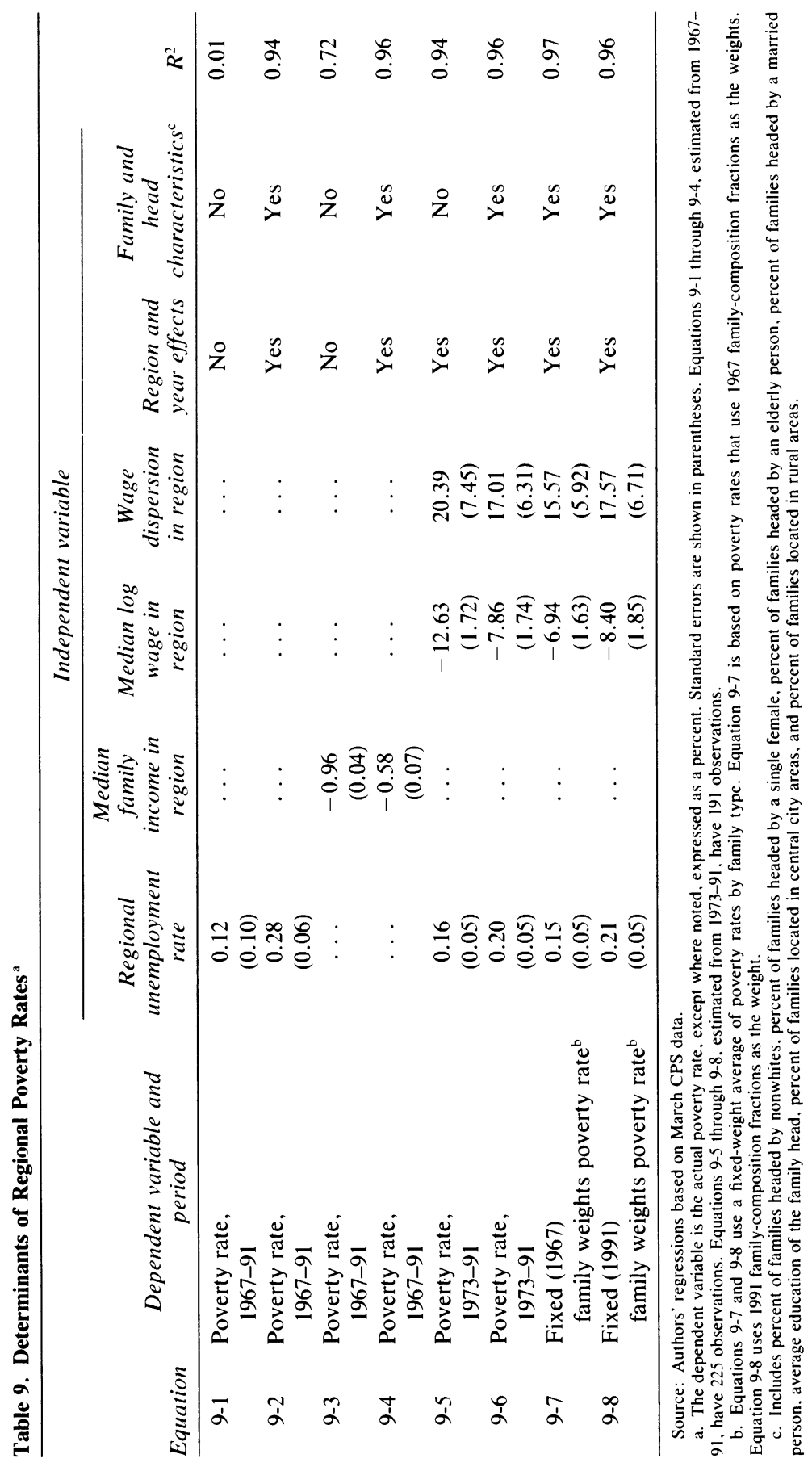


year observations, the correlation between the poverty rate and the log of the mean income of quintile 1 is -0.96 .

\section{The Determinants of Poverty Rates}

Previous research has analyzed the connection between poverty and economic growth by using annual time series observations for the United States as a whole. Our approach, using data for regions over the 1967-91 period, expands the available sample by a factor of nine and allows us to control for unobserved factors that are common across regions and are possibly correlated with poverty and observed economic changes. Table 9 presents a series of regressions for the regional poverty rate. Equations 9-1 through 9-4 are estimated over the 1967-91 period, while equations 9-5 through 9-8 are estimated over the 1973-91 subsample. Most of the specifications include unrestricted region and year effects, as well as the demographic control variables described in the notes to table 7 .

As shown in equation 9-1, without controls for region and year effects, poverty is only weakly related to unemployment. The addition of region and year effects and family characteristics, shown in equation 9-2, leads to a significant positive relation. ${ }^{36}$ This contrast suggests that other omitted factors have confounded the link between poverty and unemployment, and that these factors are captured by family characteristics and common year effects across regions. Poverty is also strongly related to median family income, as shown in equations 9-2 and 9-3. Controlling for median income, in fact, unemployment exerts only a small and statistically insignificant effect on overall poverty rates.

Equations 9-5 through 9-8 estimate the effects of labor market changes (summarized by median log wages, the standard deviation of log wages, and the unemployment rate) on poverty. As in the models for the quintile shares, all three variables are significantly related to poverty. A one percentage point rise in regional unemployment leads to a 0.2 percentage point increase in the regional poverty rate. A 0.05 increase in median wages leads to a 0.4 to 0.6 percentage point reduction in poverty. Most dramatically, a 0.05 increase in the regional dispersion in wages is associated with a 0.9 to 1.0 percentage point increase in poverty.

36. The addition of year effects alone leads to an estimated unemployment coefficient that is very close to the estimate in column 2 . 
Although the coefficients are not reported in the table, many of the demographic controls included in the models in table 9 are highly significant. For example, in equation 9-6, the average education of family heads has a coefficient of -3.1 with a $t$-statistic of 4.9 , while the percentage of black family heads has a coefficient of 0.3 with a $t$-statistic of 3.2. The effects of two variables measuring the fraction of families in rural areas and the fraction in central city areas are especially noteworthy. Some recent literature has stressed the growing isolation of inner-city neighborhoods from the rest of the economy and argued that this isolation has weakened the link between poverty and average labor market conditions.${ }^{37}$ Contrary to this story, our regressions show that increases in the fraction of the population in central city areas are actually associated with significantly lower poverty rates. On the other hand, decreases in the fraction of the rural population are also associated with reductions in poverty. Thus, as has been the case through much of the century, urbanization has been associated with less, rather than more, poverty.

\section{Poverty Rates and Changes in Family Composition}

As noted earlier, the trend toward smaller families with fewer earners per family has led to lower average family incomes. This, in turn, has presumably led to higher poverty rates. One way to quantify this effect is to compute family composition-constant poverty rates. Following Blank's 1993 work, we constructed a constant-weight poverty rate, using actual poverty rates for each family type in each year weighted by their 1967 population shares. ${ }^{38} \mathrm{We}$ also constructed an alternative fixed family-weight poverty rate using 1991 family shares. The comparison between our actual poverty rate for the United States and the two fixedweight poverty indexes is shown in figure 9 . Whereas the actual poverty rate was about the same in 1970 and 1991, the constant-weight indexes both show a steady downward trend: about 2.5 percentage points lower in 1991 than 1970 using the 1967 weights, or 3.5 percentage points lower using the 1991 weights. Thus, changing family composition has led to a secular upward trend in measured poverty rates. During the economic

37. The aggregate importance of this effect is questionable, however, given that less than 10 percent of the poor live in readily classifiable urban ghetto areas. See Jargowski and Bane (1991, table 5, p. 251).

38. Blank (1993). 
Figure 9. Poverty Rates: Actual and With Constant Family Composition, 1967-91

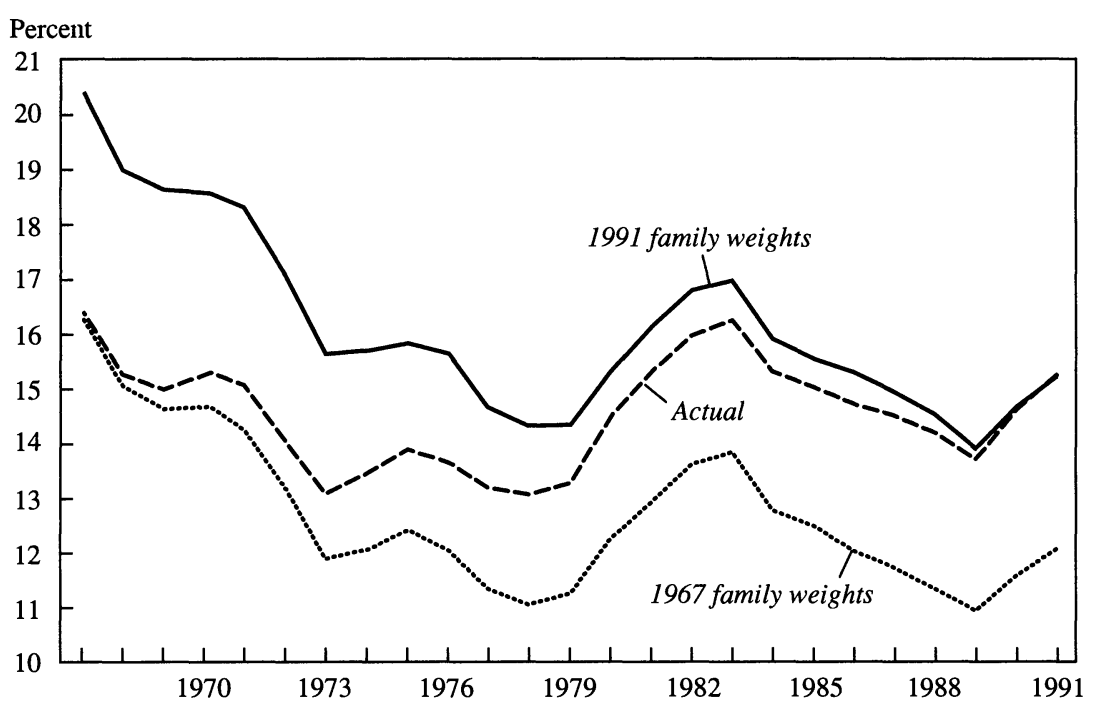

Source: Authors' calculations based on March CPS data.

expansion of the 1980s, for example, changes in family composition led poverty rates to decline 0.2 to 0.5 percentage points more slowly than they would have otherwise. ${ }^{39}$

While family composition changes affect the level of poverty, they have much less effect on the responsiveness of poverty to economic changes. Columns 7 and 8 show regression results for the same specification as in column 6, fit to the 1967-weighted and 1991-weighted poverty indexes. The results are very similar to the estimates obtained using the actual (varying-composition) poverty index.

A second way to evaluate the effect of changing composition is to fit models to the poverty rates by family type. The results of this exercise are presented in table 10. All five family types show a negative effect of median wage growth and a positive effect of wage dispersion on measured poverty rates, as shown in the second and third rows. However, the effect of unemployment (which is positive for all family types together) ranges from a strong negative for families headed by an elderly

39. The actual poverty rate index shows a fall of 2.6 percentage points in poverty between 1983 and 1989. The 1967 -weighted index shows a 2.8 percentage point fall, while the 1991-weighted index shows a 3.1 percentage point fall. 
Table 10. Determinants of Poverty Rates by Family Type, 1973-91 ${ }^{\mathrm{a}}$

\begin{tabular}{|c|c|c|c|c|c|}
\hline \multirow[b]{2}{*}{ Independent variable ${ }^{\mathrm{b}}$} & \multirow[b]{2}{*}{$\begin{array}{l}\text { Elderly } \\
\text { heads }\end{array}$} & \multicolumn{2}{|c|}{ Single heads } & \multicolumn{2}{|c|}{ Married couples } \\
\hline & & Children & $\begin{array}{c}\text { No } \\
\text { children }\end{array}$ & Children & $\begin{array}{c}\text { No } \\
\text { children }\end{array}$ \\
\hline Regional unemployment rate & $\begin{array}{r}-0.46 \\
(0.10)\end{array}$ & $\begin{array}{c}0.95 \\
(0.18)\end{array}$ & $\begin{array}{c}0.47 \\
(0.10)\end{array}$ & $\begin{array}{c}0.26 \\
(0.06)\end{array}$ & $\begin{array}{c}0.05 \\
(0.05)\end{array}$ \\
\hline Median log wage in region & $\begin{array}{c}-4.08 \\
(3.26)\end{array}$ & $\begin{array}{r}-27.86 \\
(6.00)\end{array}$ & $\begin{array}{r}-14.53 \\
(3.14)\end{array}$ & $\begin{array}{l}-5.00 \\
(2.06)\end{array}$ & $\begin{array}{r}-4.44 \\
(1.80)\end{array}$ \\
\hline Regional wage dispersion & $\begin{array}{c}14.02 \\
(13.81)\end{array}$ & $\begin{array}{c}22.87 \\
(26.11)\end{array}$ & $\begin{array}{l}18.61 \\
(13.97)\end{array}$ & $\begin{array}{l}10.86 \\
(8.19)\end{array}$ & $\begin{array}{l}8.06 \\
(7.15)\end{array}$ \\
\hline $\begin{array}{l}\text { Summary statistic } \\
\mathbf{R}^{2}\end{array}$ & 0.97 & 0.85 & 0.86 & 0.92 & 0.83 \\
\hline $\begin{array}{l}\text { Addendum } \\
\text { Mean poverty rate }\end{array}$ & $\begin{array}{c}16.86 \\
(6.01)\end{array}$ & $\begin{array}{l}41.86 \\
(5.20)\end{array}$ & $\begin{array}{l}18.89 \\
(2.84)\end{array}$ & $\begin{array}{c}7.44 \\
(2.43)\end{array}$ & $\begin{array}{c}3.67 \\
(1.43)\end{array}$ \\
\hline
\end{tabular}

Source: Authors' regressions based on March CPS data.

a. The dependent variable is the regional poverty rate for the specified family type. All samples contain 171 observations. Numbers in parentheses are standard errors, except for the last row, which shows standard deviations for the poverty rates.

b. All regressions include region and year effects, as well as family and head characteristics. Characteristics of families and heads of families, included in all regressions, are: percent of families headed by nonwhites; average education of family head; percent of families located in central city areas; and percent of families located in rural areas.

person to a strong positive for families headed by a single person with children. One interesting pattern in this table is that poverty rates of families headed by a single person are more responsive to economic change than the poverty rates of other family types. ${ }^{40}$ Other things equal, the responsiveness of poverty rates to economic changes in the labor market would have been expected to increase with the rising fraction of families headed by a single person. This is confirmed by the comparison between equations 9-7 and 9-8 in table 9: poverty rates using the 1991 weights (which give more weight to single-headed families) are more responsive to labor market changes than poverty rates using 1967 weights.

\section{The Impact of Transfers on Poverty}

There was a substantial public debate in the mid-1980s about the effect of transfers on poverty. Charles Murray claimed that government

40. Note that a comparison of mean poverty rates by family type (top row of the table) with the coefficient estimates by family type suggests that the coefficients are (roughly) proportional to the mean level of poverty. 
Table 11. Changes in Measured Poverty Rates Attributable to Government Cash Transfers ${ }^{\mathrm{a}}$

Percent

\begin{tabular}{cccccc}
\hline Year & All & $\begin{array}{c}\text { Elderly } \\
\text { persons }\end{array}$ & $\begin{array}{c}\text { Single } \\
\text { female } \\
\text { head } \\
\text { with } \\
\text { individuals }\end{array}$ & $\begin{array}{c}\text { Married } \\
\text { children }\end{array}$ & $\begin{array}{c}\text { couple } \\
\text { with } \\
\text { children }\end{array}$ \\
\hline $1979-80$ & -7.8 & -38.8 & -16.2 & -9.7 & -2.5 \\
$1982-83$ & -7.9 & -37.2 & -15.6 & -7.1 & -3.0 \\
$1988-89$ & -7.2 & -36.0 & -14.6 & -6.1 & -2.0 \\
$1990-91$ & -7.3 & -35.1 & -14.5 & -6.4 & -2.1 \\
\hline
\end{tabular}

Source: Authors' calculations of poverty rates with and without government cash transfers, as reported in U.S. Bureau of the Census (1992b, table 2).

a. Entries represent the two-year average difference between the actual poverty rate and the pretransfer poverty rate, calculated by excluding all government cash transfers from measured family income.

b. Unrelated individuals include elderly persons living alone.

antipoverty policies actually led to an increase in poverty. ${ }^{41} \mathrm{We}$ cannot directly test the role of transfers in our region-based regression models because we have no reliable data on public transfers by region over the years. Thus, the effect of transfers is subsumed in our time effects, and is implicitly assumed to be the same across regions in every year.

In recent years, the U.S. Bureau of the Census has calculated alternative poverty rates with and without government cash transfers factored into family income. Comparisons of these poverty rates, illustrated in table 11 for a few key groups, show that government cash transfers moved 7 to 8 percent of the population out of poverty during the past decade. Among the elderly, more than one-third escaped poverty because of government transfers. Among families headed by married couples-for whom fewer transfers are available-only 2 to 3 percent escaped poverty because of transfers. Comparing 1979-80 with 1988-89, the effect of transfer programs in reducing poverty changed relatively little over the decade, except among households headed by single females with children. For that group, transfers reduced poverty by nearly 10 percent at the start of the decade, but only 6 percent at the end.

As noted earlier, although we cannot include aggregate transfer expenditures in our regional equations, we can perform a second-stage analysis relating the estimated year effects from our poverty models to transfer spending and other aggregate variables. This analysis shows

41. Murray (1984). 
that the unexplained aggregate components of poverty that remain after controlling for observed labor market changes are only weakly related to transfer spending, although with a positive effect, rather than a negative one. Detailed data on transfer programs by region are clearly needed to provide further evidence on this issue. Nevertheless, we believe that the modest changes in transfer policies over the 1980s, as illustrated in table 11, probably do not lead to significant biases in our analysis of regional poverty outcomes.

\section{Summarizing the Effects of Labor Market Changes on Poverty}

Following our approach in figure 7, we can summarize the contribution of measured changes in the labor market to the course of poverty rates by comparing the actual changes in poverty rates to the unexplained changes that remain after controlling for changes in the level and dispersion of wages, and the unemployment rate. Because much of the literature has focused on changes over the 1980s, we conducted the analysis over the period 1979-89. Both the starting and ending years were cyclical peaks. The unemployment rate of 5.3 percent in 1989 was slightly lower than the 5.8 percent rate in 1979 , while the average level of real wages was also slightly lower in $1989, \$ 8.81$ per hour versus $\$ 9.23$ per hour-in 1991 dollars.

Our results are presented in table 12 . We show the actual change in poverty in the first column. The second column shows the predicted change in poverty between 1979 and 1989, using the coefficients from the models presented in tables 9 and $10 . .^{42}$ We predict the change in the poverty rate over this decade that would have occurred solely because of changes in the three labor market variables (wage levels and dispersion, and unemployment), holding constant family characteristics at their 1979 level. The third column shows the residual change in poverty that occurs exclusive of labor market changes.

The first row of table 12 suggests that labor market changes over the 1980 s predicted a larger rise in poverty than actually occurred. For all families, our model suggests that economic changes would have raised poverty rates by 0.8 percentage point. The actual poverty rate rose by

42. The first through third rows of table 12 are based on estimated coefficients in the sixth through eighth columns of table 9 , respectively. The fourth through eighth rows are based on the coefficients in the first through fourth columns of table 10 , respectively. 
Table 12. Actual and Predicted Changes in Poverty Rates from 1979 to $1989^{a}$

Percentage points

\begin{tabular}{|c|c|c|c|}
\hline Family type & $\begin{array}{c}\text { Actual change } \\
\text { in poverty }\end{array}$ & $\begin{array}{l}\text { Predicted change } \\
\text { from labor } \\
\text { market }\end{array}$ & $\begin{array}{c}\text { Unexplained } \\
\text { change }\end{array}$ \\
\hline All & 0.4 & 0.8 & -0.4 \\
\hline All (fixed 1967 weights) ${ }^{b}$ & -0.3 & 0.7 & -1.0 \\
\hline All (fixed 1991 weights) ${ }^{c}$ & -0.5 & 0.8 & -1.3 \\
\hline Elderly heads & -4.6 & 1.0 & -5.6 \\
\hline Single heads with children & 2.8 & 0.6 & 2.2 \\
\hline Single heads without children & -0.6 & 0.7 & -1.3 \\
\hline Married couples with children & 1.3 & 0.5 & 0.8 \\
\hline Married couples without children & 0.3 & 0.4 & -0.1 \\
\hline
\end{tabular}

Source: Authors' calculations based on March CPS data and tables 9 and 10.

a. Entries are differences in poverty rates from 1979 to 1989.

b. Poverty rates are fixed-weighted, using 1967 family-composition fractions as the weights.

c. Poverty rates are fixed-weighted, using 1991 family-composition fractions as the weights.

only 0.4 point; thus nonlabor market factors contributed to an "unexplained" reduction in poverty of 0.4 point. The conclusion is similar although even stronger using fixed-weight poverty indexes that hold family composition constant. Labor market changes would have increased poverty, while actual poverty fell in these data. This implies that nonmarket factors led to a decline in poverty of between 1.0 and 1.3 percentage points.

This analysis for all family types hides substantial differences among a very heterogeneous poverty population. The fourth row indicates that elderly households were the main source of the "unexplained" reduction in poverty. From 1979 to 1989 , poverty rates among elderly-headed families fell 4.6 points. Our models suggest that labor market changes alone would have increased elderly poverty; thus there is a sizable unexplained decline, consistent with continuing expansion in the nonearned income available to the elderly. A similar story emerges for childless families headed by single people. Among single heads with children, however, the opposite pattern emerges; actual poverty rates rose faster than can be explained by labor market changes alone.

Tables 10 and 12 suggest that labor market effects on poverty vary widely among different groups of the poor. Changes in the labor market have the largest impacts on poverty among single-parent families with children and the smallest effects on married couples without children. 
The observed trends in poverty over the 1980s are at least partially explained by changing labor market opportunities facing the poor, with falling unemployment rates, offset by rising wage dispersion and flat median wage levels. Certain groups, particularly the elderly and single-parent families, experienced substantial changes in poverty due to factors other than labor market change, although the labor market changes were clearly important for all groups.

\section{Summary and Conclusions}

We began this paper with a reduced-form analysis of the effects of unemployment on the income distribution. We found that each one percentage point increase in unemployment is associated with a 1.4 percent decline in average family income. Contrary to previous research, however, we found that these income losses were uniformly spread across the income distribution. Cyclical increases in unemployment led to greater increases in unemployment among poorer families. However, cyclical changes in employment were more evenly distributed across the income distribution. Because of this fact, and the fact that earnings are a smaller fraction of total family income for poorer families, the percentage income losses attributable to unemployment were almost equally distributed across families. We also analyzed the effects of median income growth using a similar reduced-form approach, and found that growth of median income has generally been associated with a modest narrowing of the family income distribution.

A more causal model of income dispersion was estimated by focusing on three key labor market factors: the level of hourly wages, their dispersion, and the unemployment rate. We found that increases in median wages were associated with a slight narrowing of the overall income distribution. This effect persisted through the 1980s, although it was somewhat weaker than in earlier years. Increases in wage dispersion had a significant redistributive effect on family earnings and incomes; we estimated that the growth of wage inequality in the 1980s reduced average incomes in the first two quintiles of the family income distribution by 4 percent, while it increased average incomes in the top quintile by 3 percent. These changes accounted for some, but not all, of the observed trends in quintile income shares over the decade. 
The final section of the paper considered the effects of unemployment, median wages, and wage dispersion on poverty rates. We found that regional poverty rates were highly correlated with median wage growth and changes in the dispersion of hourly wage rates. In light of previous findings, which suggest that poverty rates at the end of the 1980s were inexplicably high, we analyzed the effects of labor market changes over the 1980s on poverty. We also estimated the effect of changing family composition on measured poverty rates.

Negligible real wage growth, coupled with growing wage dispersion, implies that poverty rates should have increased over the 1980s. Trends in family composition reinforced this trend. In fact, the increase in the overall poverty rate from 1979 to 1989 (the end of the 1980s expansion) was slightly less than predicted. This result is driven by continued improvements in the living standards of the elderly, whose poverty rates have fallen far more than labor market indicators would have predicted. Among families with children, on the other hand, poverty grew faster during the 1980s than can be explained by changes in the level and dispersion of wages and changes in unemployment.

Our overall conclusion is that family income and poverty are closely related to conditions in the labor market. The failure of poverty rates to respond to robust GDP growth during the 1980s is due to the combination of slow productivity growth and widening wage inequality that accompanied the expansion of the 1980s. 


\section{Comments and Discussion}

Frank Levy: In this interesting and thoughtful paper, Rebecca M. Blank and David Card address the "new view" that poverty and income inequality no longer respond to macroeconomic expansion. The authors extend traditional "trickle-down" studies in two major ways. First, they disaggregate CPS data into nine census regions, which increases their observations by an order of magnitude.

Second, they describe an economy using three variables: two traditional measures-median household income and the unemployment rate-and a measure of wage dispersion. If earlier trickle-down studies had included a dispersion measure, it probably would have been insignificant; wage dispersion was generally too stable. But in the 1980 s, the long expansion, combined with rapidly widening wage inequality, gives a dispersion measure a definite statistical role.

With these extensions, the authors conclude that the old view still has some life. Together, the macroeconomic variables (including dispersion) can still do a good job of predicting the poverty rate and changes in quintile shares. But there are some surprises. When the data are controlled for regional effects, lower unemployment does little to reduce household income inequality (contrary to studies done on national aggregates). Similarly, without regional effects, lower unemployment does little to reduce poverty.

I found the paper interesting. I believe it could be further improved by sharpening one or two issues and looking at a third: the role of poverty concentration.

The first issue that needs to be sharpened is the meaning of economic growth. Blank and Card's need to add a dispersion term to the traditional model indicates that the most recent "rising tide" was different from the expansions of the 1950s and 1960s. This difference can be illustrated through a little history. 
In 1982, while writing Losing Ground, Charles Murray advanced a standard trickle-down theory of poverty reduction. ${ }^{1}$ Writing in the Public Interest, he noted that when real income per household had grown rapidly in the 1950s and 1960s, the poverty rate had fallen. When real income per household stagnated after 1973, the poverty rate stagnated too. What I will call Old Murray concluded that the growth of real incomes-not the growth of transfers or the War on Poverty-had caused poverty to decline in the 1960s. This is what I would call a neo-Tobinian view of poverty reduction, and most members of the Brookings Panel, including me, would agree.

By the time Murray finished Losing Ground, he had come to measure economic growth in a different way, using real income per capita, rather than income per household. This led to a more provocative conclusion: that economic growth was as strong in the 1970s and early 1980 s as it had been in the 1950s, and yet the poverty rate was stagnant. This was one of the first statements of the new view: that a rising tide no longer lifted all boats. According to the New Murray, the problem lay in an overly generous welfare state, which induced many poor families to leave the labor market. ${ }^{2}$

As I noted, I am a believer in Old Murray. In practice, the importance of reducing poverty through rising real wages even exceeds the importance of the unemployment rate. To illustrate, two recessions occurred in the 1950s, including a quite severe one that ended the decade. Yet real wages and median income rose sharply, and retrospective applications of the poverty standard show the poverty rate falling from about 31 percent in 1949 to 22 percent in 1959.

If one accepts this view-that real wage growth (adjusted for dispersion) has the biggest influence on poverty rates ${ }^{3}$ - then the 1980 s were

1. Murray (1982).

2. As is well known, income per capita continued to rise after 1973 not because wages grew, but because the composition of the population shifted toward workers and away from dependents. This trend, however, was more important for husband-wife families (who shifted to two earners) and young adults (who postponed having children) than for the rapidly growing number of families headed by single women.

3. The issue of dispersion also arises in Blank (1993). Blank finds that a standard macroeconomic equation substantially overestimates the poverty reduction that occurred in the 1980s. At least part of this overestimate seems to occur because Blank's measure of real income is based on mean, rather than median, household income. During the 1980s, income growth was heavily concentrated in the distribution's upper tail, so changes in mean household income would have a much smaller impact on poverty than in earlier years. 
not much to write home about. The table below compares it with two earlier periods. In the first two data columns, I decompose GNP growth into two components: the annual growth of hours worked and the annual growth in output per hour. It is, of course, the second term that is most interesting. The third data column adjusts output per hour for what Barry Bosworth has called the "terms of trade" between sectors: the difference between the increase in the GNP deflator (which adjusts output per hour) and the CPI or a consumption deflator (which is used in official poverty statistics). ${ }^{4}$

\begin{tabular}{cccc}
\multicolumn{4}{c}{ Percent per year } \\
Period & $\begin{array}{c}\text { Hours } \\
\text { worked }\end{array}$ & $\begin{array}{c}\text { Output } \\
\text { per hour }\end{array}$ & $\begin{array}{c}\text { Output per hour } \\
\text { adjusted for }\end{array}$ \\
$1959-73$ & 1.01 & 2.81 & 3.22 \\
$1973-79$ & 1.79 & 0.74 & 0.74 \\
$1979-89$ & 1.45 & 0.99 & 0.98
\end{tabular}

In sum, while there was not much poverty reduction in the 1980s, there was not much economic growth, either-at least of the kind that counted. It would be useful to make this point clearly to underline the fact that part of the new view was based on a faulty measure of the economy's performance. At the same time, the economy's performance in the 1980s raises the possibility that factors beneath the surface were changing in ways that will undermine the ability of future economic growth to reduce poverty. The New Murray may be right in the future, even if he was not right in the past. I will return to this point in a moment.

A second issue that needs sharpening is the story told by the regional dummies. As the authors mention in passing, some regions are surrogates for specific industries: for example, the southwest for energy. More generally, the recoveries of the 1970s and 1980s were very different in their regional patterns. Demographers describe much of the 1970s as a "rural renaissance." In a sharp reversal of form, both nonmetropolitan areas and small metropolitan areas (those with fewer than one million people in 1970) grew faster than large metropolitan areas.

The reasons are not hard to ascertain. The food shortage of the early 1970s stimulated the agricultural economy, the 1973 oil price increase

4. Ideally, further correction should be made for the proportion of compensation that is paid in health insurance and other kinds of income not counted in standard poverty calculations. 
stimulated energy production, and the rapidly falling value of the dollar helped support durable goods manufacturing. The boom in the heartland meant a boom in the demand for blue collar labor, which helped limit the growth of wage dispersion during the decade.

The 1980s, the decade of the bicoastal economy, precisely reversed this story, while the early 1990s, the years of the bicoastal recession, may be reversing things again. In any case, a more detailed interpretation of regional effects wouid provide an added bonus (beyond simply more degrees of freedom) for the authors' organization of data.

A smaller point involves Blank and Card's treatment of demographics. At various points, the authors try to examine the impact of changing household structure on both income inequality and poverty. In these investigations, they look at changes in heads of households, but they do not separately examine the shift from one- to two-earner couples. The shift is important, particularly in the last decade, when it appears that most of the increase in women's labor supply took place among the wives of husbands with high earnings. This is a change from earlier decades; recent work by Paul Ryscavage and his colleagues suggests it may have contributed to income inequality. ${ }^{5}$

Finally, let me turn to the issue that is not in the paper: the concentration of poverty in cities. At the paper's beginning, the authors outline two competing hypotheses to explain why economic growth has apparently failed to reduce poverty. One theory is the declining labor supply of the poor, but this is really an umbrella for many different theories, one of which is the growth of an underclass. In the mid-1980s, the underclass was given a geographic content through the work of William J. Wilson, among others. ${ }^{6}$ It is clear that over the period studied by the authors, poverty has increasingly become a problem of the central cities.

In 1970, central-city poor accounted for only about one-third of all poor in the nation and the central-city poverty rate was 0.14 . In 1990, central cities accounted for 42 percent of all poor and the central-city poverty rate was 0.20 . The shift was particularly dramatic for children. Central cities now contain 45 percent of all poor children, and almost one in three central-city children is poor.

Being poor is not the same as being part of the underclass. But as middle-class blacks and whites continue to leave cities, one must wonder

5. U.S. Bureau of the Census (1992c).

6. Wilson (1987). 
about the culture being left behind. Consider as an indicator the recent increase in murder rates. Between the mid-1970s and the mid-1980s, murder rates for all demographic groups were quite stable. Between 1985 and 1991, murder rates for older teenagers rose substantially. In particular, the number of murders of black young men and women, aged $15-19$, rose from 657 in 1985 to 1,600 in 1991. If we assume that 80 percent of these murder victims were males, a constant murder rate at the 1991 level suggests that a black male fifteen year old has a 1-in-200 chance of being murdered before he turns 20 . This number suggests something seriously wrong that the standard economic indicators cannot capture. Looking more carefully at the effect of cities, as well as regions, may give more clues as to what is happening here.

James L. Medoff: Rebecca M. Blank and David Card's study of U.S. poverty rates over the past twenty-five years is an example of creative and instructive empiricism. The statistical analysis is unique in relying on regressions of regional, as opposed to national, data on poverty, unemployment, and per capita income. In addition, by focusing on income quintiles, the study provides many insights lost in more aggregate investigations.

Two of the study's findings most affect my thinking about national poverty statistics. First, changes in regional poverty rates depend more on changes in regional median income than on regional rates of unemployment. This is shown in table 7. Second, from 1967-79, the bottom two income quintiles suffered the greatest deterioration in earnings. This is described in table 5.

My comments are limited to national data, but my statistics are quite consistent with the authors' conclusions. The main difference is that I focus on the downward trend in the availability of jobs for those who need them to avoid poverty.

In April 1992, I wrote a paper called "The New Unemployment" in which I noted that one of the main characteristics of the post-1980 unemployment is that if workers lost their jobs, their loss was much more likely to be permanent than temporary. ${ }^{1}$ As is well documented elsewhere, job losers not "on layoff" are unlikely to return to their old jobs.

1. Medoff (1992). The significance of the relative rise in permanent job loss in the latest recession was also emphasized by George Perry and Charles Schultze in their paper in BPEA, 1:1993. 
I refer to them here as "permanent job losers." People who are laid off can with very good reason expect to be recalled to their old firm. While 76 percent of all job losers were permanent job losers in February 1992 (when payroll employment reached its downturn trough), that percentage was significantly lower (66 percent) in the November 1982 trough and even lower (59 percent) in the trough of March 1975.

Another salient fact about the new unemployment is that white collar workers face a higher risk of joining the ranks of the newly unemployed during a cyclical downturn. To be more precise, while the ratio of the number of newly unemployed white collar workers to the number of newly unemployed blue collar workers was only about 0.20 in the January-July downturn in 1980, it rose markedly to 0.40 between July 1981 and November 1982, and even more sharply to 0.93 in the recession from July 1990 to February 1992.

Katharine Bradbury of the Federal Reserve Bank of Boston was one of the first to note that many of these newly unemployed white collar workers came from occupations and industries in which median pay was relatively low. ${ }^{2}$ Among all occupations, the group that suffered the largest absolute growth of unemployment was managers and professionals (from 0.795 million to 1.007 million). This group, of course, is very well paid on average and thus attracted a great deal of media attention. Much less discussed was the fact that the only other occupational group that suffered increased unemployment between 1983 and 1992 was the on-average poorly paid technical, sales, and administrative category (in which unemployment grew from 2.116 million to 2.268 million).

"The New Unemployment" presented evidence-summarized here in table D1-that strongly implies that the amount of hiring activity per unemployed worker plummeted in the years after 1980 .

This plummeting NHWI/UR ratio motivated James Tobin to look closely at changes in employment in a presentation he made to the Joint Economic Committee on February 1, 1993. He noted that while in the twenty months after the November 1982 trough employment grew by about 6.5 million, it grew by only about 0.5 million in the twenty months after the trough of March 1992.

Harvard economics graduate student Andrew Harless portrayed this country's anemic post-1980 job generation somewhat differently. ${ }^{3}$ Us-

2. Bradbury (1993).

3. Harless (1992). 
Table D1. The Post-1980 Shortage of Jobs for the Unemployed

\begin{tabular}{|c|c|c|c|}
\hline Year & $\begin{array}{l}\text { Civilian } \\
\text { unemployment } \\
\text { rate }(\mathrm{UR})\end{array}$ & $\begin{array}{c}\text { Normalized } \\
\text { help-wanted } \\
\text { index }(N H W I)^{\mathrm{a}}\end{array}$ & $N H W I / U R$ \\
\hline 1980 & 7.1 & 100.2 & 14.1 \\
\hline 1984 & 7.5 & 97.3 & 13.0 \\
\hline 1991 & 6.7 & 60.7 & 9.1 \\
\hline 1992 & 7.4 & 59.4 & 8.0 \\
\hline
\end{tabular}

Source: The civilian unemployment rate (UR), measured in percent, and an index of nonagricultural paid employment (EI) are from the Bureau of Labor Statistics. The help wanted index (HWI) was produced by the Conference Board.

a. The normalized help wanted index (NHWI) is defined as HWI/EI. The NHWI was constructed so that it equaled 100 in 1985.

ing the empirical relationships between the normalized help wanted index, the unemployment rate, and inflation, he estimated that the current rate of unemployment associated with nonaccelerating inflation is well below 5 . The corresponding employment gap for the most recent recession has been exceeded only once (1982-83) in the past thirty years.

In "The New Unemployment," I used four CPS microdata sets (May of 1979, 1983, and 1988, and January 1991) that indicated how long employees had worked for their current firms. I defined employees with less than one year of company service as new hires. I then constructed an index of the median real usual weekly earnings of these short-service workers. This index fell from 100 in May 1979 to 89 in January 1991. Although the unemployment rate fell from 10.1 percent in May 1983 to 5.6 percent in May 1988, this index of median earnings of new workers remained at 91. Among all workers, the analogous index equaled 100 in 1979, 94 in 1983, 96 in 1983, and 95 in 1991. Thus, while these were bad times for most wage and salary earners, they were especially bad for those new to a job.

Many of those unemployed after 1980 were unable to secure any job at all. Since nearly all of the income of most adults comes from the labor market, I believe that changes in hiring must be critical in explaining changes in the rate of poverty. Before 1980, when changes in hiring intensity seesawed smoothly with changes in the unemployment rate, it did not much matter which variable one chose for an econometric investigation. However, after 1980, changes in these two measures of labor market conditions stopped moving in sync. Thus, it was now possible to assess whether changes in the unemployment rate without accompanying changes in hiring activity were associated with changes in the rate of poverty. 
Table D2. Explaining the Percent of Persons in Poverty with Jobs Variables ${ }^{\text {a }}$

\begin{tabular}{|c|c|c|c|}
\hline \multirow[b]{2}{*}{ Independent variable } & \multicolumn{3}{|c|}{ Parameter estimates } \\
\hline & $\begin{array}{c}\text { Regression } \\
\quad 1\end{array}$ & $\begin{array}{l}\text { Regression } \\
\quad 2\end{array}$ & $\begin{array}{c}\text { Regression } \\
3\end{array}$ \\
\hline $\begin{array}{l}\text { Change in the } \\
\text { unemployment rate }\end{array}$ & $\begin{array}{c}0.471 \\
(0.094)\end{array}$ & $\begin{array}{c}0.046 \\
(0.154)\end{array}$ & $\begin{array}{c}0.124 \\
(0.180)\end{array}$ \\
\hline $\begin{array}{l}\text { Change in the normalized } \\
\text { help wanted inde } \mathrm{x}^{\mathrm{b}}\end{array}$ & $\ldots$ & $\begin{array}{r}-0.034 \\
(0.011)\end{array}$ & $\begin{array}{r}-0.033 \\
(0.012)\end{array}$ \\
\hline $\begin{array}{l}1980 \text { Dummy variable } \\
(1980 \text { or later }=1)\end{array}$ & $\cdots$ & $\cdots$ & $\begin{array}{c}0.545 \\
(0.578)\end{array}$ \\
\hline $\begin{array}{l}\text { Change in unemployment } \\
\text { rate } \times 1980 \text { Dummy }\end{array}$ & $\ldots$ & $\ldots$ & $\begin{array}{c}0.034 \\
(0.517)\end{array}$ \\
\hline $\begin{array}{l}\text { Change in normalized } \\
\text { Help Wanted Index } \times \\
1980 \text { Dummy }\end{array}$ & $\ldots$ & $\ldots$ & $\begin{array}{c}0.020 \\
(0.042)\end{array}$ \\
\hline $\mathbf{R}^{2}$ & 0.525 & 0.679 & 0.712 \\
\hline
\end{tabular}

Intuitively, it seemed quite obvious that deterioration in this activity would increase poverty even if the unemployment rate remained unchanged. Table D2 presents three regressions that provide evidence that this intuition is quite correct. The regressions reveal that throughout the past twenty-five years, the change in hiring activity (as assessed by change in the normalized help wanted index) was the labor market characteristic most associated with change in the rate of poverty. While the association was somewhat weaker in the years after 1980 than it was from 1967-79, this weakening does not explain the dramatic post-1980 growth in the poverty rate. What does is the fact that after 1980, less unemployment no longer meant more hiring to the extent that it had prior to the 1980 s.

Olivier Blanchard has observed that to demonstrate fully that a shortage of hiring activity caused the rise in the rate of poverty, I had to demonstrate that those in the greatest need of jobs were unable to secure them.

The first fact that should be noted is that between December 1979 and December 1992, the percent of the unemployed who were jobless for fifteen weeks or more rose from 20.2 to 38.6. In the entire set of 1979-92 
December percentages, the "fifteen weeks or more" percentage exceeded 38.6 only once in the month after the trough of the deepest postwar recession (in December 1982), when it equaled 38.8.

The fact that those with low predicted earnings found it particularly hard to land a job is supported in May Current Population Survey data for 1975, 1984, and 1992. These surveys indicate that among the unemployed in the third predicted earnings decile from the bottom, the percentage unemployed for fifteen weeks or more rose from 25.6 to 27.1 to 30.3. ${ }^{4}$ Among the unemployed whose predicted earnings placed them in the fourth decile from the bottom, the comparable percentages were $33.7,35.4$, and 37.5. In 1992 dollars, those in the third decile from the bottom had predicted usual weekly earnings of $\$ 317$; in the fourth decile from the bottom, median predicted earnings were $\$ 401$. While individuals earning from $\$ 16,000$ to $\$ 21,000$ a year are not among the very worstoff American workers, they will rarely have resources to sustain them for fifteen or more weeks without any earnings.

In light of these figures relating predicted earnings to spells of joblessness, I examined the plight of the unemployed in the lowest paid white collar occupations: technical, sales, and administrative, from 1983-92; and clerical plus sales, from 1971 to 1983 . The technical, sales, and administrative group was one of only two broad occupational categories with greater unemployment in 1992 than in 1983. The only other category in which unemployment rose was managers and professionals.

The data in table D3 indicate the percentage of the unemployed from the low-earnings (clerical plus sales) and technical, sales, and administrative occupational groupings who were unemployed for at least fifteen weeks at various points from 1971 to 1992.

These figures demonstrate forcefully that, since 1980, the lowest paid group of unemployed white collar workers has found it harder and harder to earn a living that would enable them to avoid poverty. As was seen above, they certainly were not the only vulnerable workers who suffered long spells of joblessness.

It should be noted that 1982 long-term unemployment percentages were calculated under each of BLS's two most recent occupational clas-

4. These predicted usual weekly earnings figures were based on regressions of $\ln$ (usual weekly earnings) with 1992 Current Population Survey data that controlled for age, race, sex, education, state of residence, and standard metropolitan statistical area (SMSA) status. 
Table D3. Long Unemployment among Low-Paid White Collar Workers

\begin{tabular}{ccccc}
\hline & & \multicolumn{3}{c}{$\begin{array}{c}\text { Percent of unemployed in groups } \\
\text { unemployed for 15 or more weeks }\end{array}$} \\
\cline { 2 - 5 } Year & $\begin{array}{c}\text { Civilian } \\
\text { unemployment } \\
\text { rate (percent) }\end{array}$ & Clerical & Sales & $\begin{array}{c}\text { Technical, } \\
\text { Sales, and } \\
\text { Administrative }\end{array}$ \\
\hline 1971 & 5.9 & 23.1 & 22.0 & n.a. \\
1977 & 7.1 & 28.0 & 28.3 & n.a. \\
1982 & 9.7 & 31.4 & 29.2 & 30.3 \\
1983 & 9.5 & n.a. & n.a. & 36.6 \\
1984 & 7.5 & n.a. & n.a. & 29.4 \\
1992 & 7.4 & n.a. & n.a. & 37.4 \\
\hline
\end{tabular}

Source: Bureau of Labor Statistics.

sification schemes. The similarity of the 1982 figures implies strongly that the 1971 to 1992 data can be treated as one twenty-one-year continuous time series. Under this assumption, table D3 reveals that the percentage of low-wage unemployed white collar workers who searched a very long time for employment rose sharply from about 22 percent in 1971 to about 37 percent in 1992. Clearly, the ability of many low-paid unemployed white collar workers to avoid poverty diminished greatly during this period. Moreover, if years with roughly similar unemployment rates are compared, it seems that this trend is secular, not cyclical.

In sum, it appears quite clear that since 1980, many economically vulnerable unemployed individuals have had great difficulty in securing employment and earnings. It is not at all surprising that this difficulty has been reflected in post-1980 U.S. poverty rates.

\section{General Discussion}

James Tobin suggested that this paper should be understood as examining whether the poverty-reducing effects of economic growth have remained constant, once important factors such as unemployment, family composition, and wage dispersion have been controlled for. Tobin went on to note that-even if the macroeconomic success of the early postwar period returned-poverty rates would not decline as fast now as between the 1930s and 1960s for two reasons. First, the migration from the rural South, which was an important factor reducing poverty in the ear- 
lier period, has stopped. Second, there are inevitable diminishing returns to growth in reducing poverty because of the narrowing in the lower tail of the income distribution. The farther out in the lower tail a poverty line falls, the smaller will be the area that moves above the poverty line for any given rightward shift of mean income.

Some panel members suggested that Rebecca Blank and David Card's paper would have benefited from more explicit treatment of major factors affecting income. Henry Aaron argued that to understand the link between economic growth and poverty one needs to analyze the specific mechanisms by which growth might affect poverty: labor force participation, hours employed, wage rates, and transfer payments. Gary Burtless focused on the role of government transfer payments. Although increases in the real wage are important for many families, they do not help families whose income comes from other sources. He noted that an earlier work by Blank showed that the different rates of increase in government transfers in the 1960s and 1980s explained an important part of the differences in the poverty reduction in those two decades.

Robert Gordon focused on the role of real wage growth and factors that might affect it. He suggested that the first-order explanation for why the poverty rate stopped declining was that real earnings stopped growing. The direct explanation for the stagnation of real earnings is the sluggishness in productivity growth. But he cautioned that causality can run in the reverse direction: an ample supply of low-wage workers can reduce the necessity for businesses to increase their productivity. And in this case, immigration could affect the supply of low-wage workers and real earnings. In addition, Gordon reported results by George Johnson and Frank Stafford suggesting that an increased supply of goods from abroad reduces the rents earned by high school graduates. Card strongly disagreed with Gordon's suggestion on immigration, reporting that it was rejected by his own research on wages of low-wage workers in Miami in the five years after the Mariel Boatlift.

Chris Sims turned to issues related to the regional disaggregation used in the paper. He suggested that the authors' results might change if they accounted for migration. For example, it could be that unemployment does not affect the income distribution of a region because unemployed people move out. William Nordhaus noted that an earlier Brookings paper by Olivier Blanchard and Larry Katz suggested that migration significantly mitigates the effects of regional cycles. But Card 
argued that migration across regions is a relatively small phenomenon, especially as a short-term response. Blank added that interregional movement of low-income households is especially rare. Nordhaus also pointed out that regional and national cycles can have very different effects on the income distribution within a region. A person whose income derives from a portfolio of the S\&P 500 likely would fare better in a regional downturn than a very immobile worker whose income derives entirely from labor. On the other hand, a national slowdown might have a larger effect on the income of the S\&P 500-holder.

Paul Romer acknowledged the authors' evidence that changes in family composition have not affected the responsiveness of poverty to growth, but asked how important family composition was for understanding poverty levels during the 1980s. Card indicated that changes in family composition did matter in the 1980 s, but that the splintering of families is a long-term trend that began well before the 1980s; in fact, there were bigger changes between 1969 and 1979 than during the 1980s. Robert Hall brought up the role of relative prices in gauging poverty. If poverty were defined as the inability to purchase a basket of goods, it would have declined substantially in the 1980s, reflecting a decline in the relative price goods. The problem is that the relative prices of other items in the consumption bundle, such as housing and utilities, rose rapidly. Hall questioned whether the CPI is sufficiently accurate on housing prices to be trusted. Frank Levy replied that the PCE deflator for housing-which does not suffer from the same problems as the CPI-yields the same story for real wages.

Part of the discussion centered on the usefulness of the Help Wanted Index in explaining poverty and employment trends. James Medoff suggested that the Index is related to poverty because changes in the Index capture shifts in the Beveridge curve and thus changes in the vulnerability of the unemployed. Robert Hall added that 6 percent unemployment is today associated with worse problems than it was twenty years ago, because more unemployment is permanent today. 


\section{References}

Baily, Martin Neil, and Robert J. Gordon. 1988. "The Productivity Slowdown, Measurement Issues, and the Explosion of Computer Power." BPEA, 2:1988, 347-420.

$\rightarrow$ Beach, Charles M. 1977. "Cyclical Sensitivity of Aggregate Income Inequality." Review of Economics and Statistics 59(1): 56-66.

$\rightarrow$ Bils, Mark J. 1985. "Real Wages over the Business Cycle: Evidence from Panel Data." Journal of Political Economy 93(4): 666-89.

Blanchflower, David G., and Andrew J. Oswald. Forthcoming. The Wage Curve. Cambridge: MIT Press.

Blank, Rebecca M. 1993. "Why Were Poverty Rates So High in the 1980s?" In Poverty and Prosperity in the USA in the Late Twentieth Century, edited by Dimitri B. Papadimitriou and Edward N. Wolff. New York: St. Martin's Press.

Blank, Rebecca M., and Alan S. Blinder. 1986. "Macroeconomics, Income Distribution, and Poverty." In Fighting Poverty: What Works and What Doesn't, edited by Sheldon H. Danziger and Daniel H. Weinberg. Cambridge, Mass.: Harvard University Press.

Bradbury, Katharine L. 1993. "Shifting Patterns of Regional Employment and Unemployment: A Note." New England Economic Review (Sept./Oct.): 3-12.

Card, David, and W. Craig Riddell. 1993. "A Comparative Analysis of Unemployment in the United States and Canada." In Small Differences That Matter: Labor Markets and Income Maintenance in Canada and the United States, edited by David Card and Richard B. Freeman. Chicago: University of Chicago Press.

Cutler, David M., and Lawrence F. Katz. 1991. "Macroeconomic Performance and the Disadvantaged." BPEA, 2:1991, 1-61.

DiNardo, John, and Thomas Lemieux. 1993. "Diverging Male Wage Inequality in the United States and Canada, 1981-1988: Do Unions Explain the Difference?" Paper prepared for the Summer 1993 NBER Labor Studies Meeting.

Harless, Andrew D. 1992. "Sectoral Shifts Revisited." Unpublished paper. Harvard University (April).

Jargowski, Paul A., and Mary Jo Bane. 1991. "Ghetto Poverty in the United States, 1970-1980." In The Urban Underclass, edited by Christopher Jencks and Paul E. Peterson. Washington: Brookings.

$\rightarrow$ Juhn, Chinhui, Kevin M. Murphy, and Brooks Pierce. 1993. "Wage Inequality and the Rise in Returns to Skill." Journal of Political Economy 101(3): 410-42.

Karoly, Lynn A. 1993. "The Trend in Inequality Among Families, Individuals, and Workers in the United States: A Twenty-Five Year Perspective." In Uneven Tides, edited by Sheldon Danziger and Peter Gottschalk. New York: The Russell Sage Foundation. 
Levine, Phillip B. 1992. "Demographic Differences in the Cyclical Sensitivity of Labor Market Behavior." Unpublished paper. Wellesley College (April).

$\rightarrow$ Levy, Frank, and Richard J. Murnane. 1992. "U.S. Earnings Levels and Earnings Inequality: A Review of Recent Trends and Proposed Explanations." Journal of Economic Literature 30(3): 1333-81.

Medoff, James L. 1992. "The New Unemployment." Unpublished paper prepared for Sentor Lloyd Bentsen, Joint Economic Committee, U.S. Congress (April). (Revised August 1993)

Murray, Charles A. 1982. "The Two Wars Against Poverty: Economic Growth and the Great Society." Public Interest 69: 3-16. 1984. Losing Ground: American Social Policy, 1950-80. New York: Basic Books.

Ruggles, Patricia. 1990. Drawing the Line: Alternate Poverty Measures and their Implication for Public Policy. Washington: The Urban Institute Press.

Slottje, Daniel J. 1989. The Structure of Earnings and the Measurement of Income Inequality in the U.S. Amsterdam: North-Holland.

Tobin, James. Forthcoming. "Poverty in Relation to Macroeconomic Trends, Cycles, and Policies." In Poverty and Policy, edited by Sheldon Danziger, Gary Sandefur, and Daniel Weinberg. Cambridge, Mass.: Harvard University Press.

U.S. Bureau of the Census. 1991. "Money Income of Households, Families and Persons in the United States: 1990." Current Population Reports Series P-60, Number 174. Washington: Department of Commerce.

- 1992a. "Poverty in the United States: 1991." Current Population Reports Series P-60, Number 181. Washington: Department of Commerce. 1992b. "Measuring the Effect of Benefits and Taxes on Income and Poverty: 1979 to 1991." Current Population Reports Series P-60, Number 182. Washington: Department of Commerce.

- 1992c. "Studies in the Distribution of Income." Current Population Reports Series P-60, Number 183. Washington: Department of Commerce.

Wilson, William J. 1987. The Truly Disadvantaged: The Inner City, the Underclass, and Public Policy. Chicago: University of Chicago Press. 